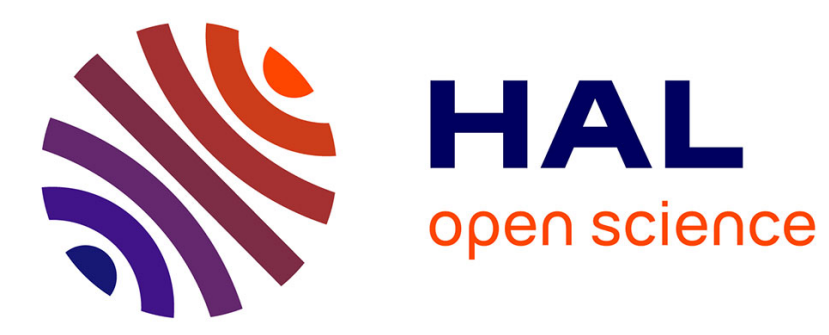

\title{
Numerical models for continental break-up: Implications for the South Atlantic
}

A Beniest, A Koptev, Evgenii Burov

\section{To cite this version:}

A Beniest, A Koptev, Evgenii Burov. Numerical models for continental break-up: Implications for the South Atlantic. Earth and Planetary Science Letters, 2017, 461, pp.176-189. 10.1016/j.epsl.2016.12.034 . hal-01467320

\section{HAL Id: hal-01467320 https://hal.sorbonne-universite.fr/hal-01467320}

Submitted on 14 Feb 2017

HAL is a multi-disciplinary open access archive for the deposit and dissemination of scientific research documents, whether they are published or not. The documents may come from teaching and research institutions in France or abroad, or from public or private research centers.
L'archive ouverte pluridisciplinaire HAL, est destinée au dépôt et à la diffusion de documents scientifiques de niveau recherche, publiés ou non, émanant des établissements d'enseignement et de recherche français ou étrangers, des laboratoires publics ou privés. 


\section{Numerical models for continental break-up: implications for the South Atlantic}

Beniest, A. ${ }^{1,2}$, Koptev, A. $^{1}$ Burov, E. ${ }^{1 \text { T }}$

Email corresponding author: a.beniest@gmail.com

1. Sorbonne Universités, UPMC University Paris 06, CNRS, Institut des Sciences de la Terre de Paris (iSTeP), 4 Place Jussieu 75005 Paris, France

2. IFP Energies nouvelles, Geosciences, 1\&4 Avenue du Bois-Préau 92852, Rueil-Malmaison, France

T Deceased 9 October 2015

\section{Abstract}

We propose a mechanism that explains in one unified framework the presence of continental break-up features such as failed rift arms and high-velocity and high-density bodies that occur along the South Atlantic rifted continental margins. We used 2D and 3D numerical models to investigate the impact of thermo-rheological structure of the continental lithosphere and initial plume position on continental rifting and breakup processes. 2D experiments show that break-up can be 1) "centred", mantle plume-induced and directly located above the centre of the mantle anomaly, 2) "shifted", mantle plume-induced and 50 to 250 $\mathrm{km}$ shifted from the initial plume location or 3) "distant", self-induced due to convection and/or slabsubduction/delamination and 300 to $800 \mathrm{~km}$ off-set from the original plume location. With a 3D, perfectly symmetrical and laterally homogenous setup, the location of continental break-up can be shifted hundreds of km's from the initial position of the mantle anomaly. We demonstrate that in case of shifted or distant continental break-up with respect to the original plume location, multiple features can be explained. Its deep-seated source can remain below the continent at one or both sides of the newly-formed ocean. This mantle material, glued underneath the margins at lower crustal levels, resembles the geometry and location of high velocity/high density bodies observed along the South Atlantic conjugate margins. Impingement of 
27 vertically up-welled plume material on the base of the lithosphere results in pre-break-up topography

28 variations that are located just above this initial anomaly impingement. This can be interpreted as aborted

29 rift features that are also observed along the rifted margins. When extension continues after continental

30 break-up, high strain rates can relocalize. This relocation has been so far attributed to rift jumps. Most

31 importantly, this study shows that there is not one, single rift mode for plume-induced crustal break-up.

32

\section{Introduction}

Over the last decades a large variety of rift features have been recognised and explained with different methods and different concepts. These features include for example aborted rift structures, anomalous topography or anomalously high velocity/high density bodies located in the lower crust. Explanations for anomalous features often link one mechanism with one observed rift feature. For example, on plume impingement, a stratified lithospheric rheology (e.g. D’Acremont et al., 2003; Burov et al., 2007;) would result in topographic uplift, as has been modelled with thermo-mechanical modelling. Forward modelling shows that magmatic underplating can cause topographic variations (Hirsch et al., 2010). Anomalously high velocity/high density bodies have been observed on tomographic images below the continents, implying that in some regions magmatic processes dominate rifting (Cornwell et al., 2006). The latter is also suggested by gravity modelling that revealed the presence of anomalously high-density bodies in e.g. the South Atlantic domain, implying that volcanic activity played a key role in margin development (Blaich et al., 2011; Maystrenko et al., 2013).

Review papers combine all these studies on one specific topic. Examples are the role of the Moho in extensional settings (Cloetingh et al., 2013), the effect of volcanism in rifting and continental break-up (Franke, 2013) or the dynamic processes that control rifting (Ziegler and Cloetingh, 2004).

With this study we demonstrate how one break-up mechanism can explain a multitude of features. We use the South Atlantic break-up as our case study for plume-induced continental break-up. Since the South Atlantic developed diachronously and it is a very complex region requiring a 3D approach, we have not the intension to reproduce the South Atlantic evolution as such, including along-axis northward break-up 
53 propagation to close to the plume (Franke, 2013), but rather to address general observations on continental

54 break-up. Our fully coupled lithospheric-grade 2D and 3D models have an explicit elasto-visco-plastic

55 rheology that accounts for realistic deformation of the lithosphere and a slip free surface that can calculate

56 vertical motions. The 2D model has proven to be very useful to investigate plume-lithosphere interactions

57 (e.g. d'Acremont et al., 2003; Burov et al., 2007). We take it one step further by developing one scenario to

58 explain multiple anomalous features, such as high-velocity/high-density bodies and anomalous topographic

59 variations with one single model. The 3D model is used to include the lateral component in a very simple,

60 completely lateral homogeneous setting (Koptev et al., 2016).

61

\section{Geological and geophysical setting}

\section{2.1. South Atlantic opening}

64 Initial extension between Africa and South America was accommodated along a former fold-and-thrust belt

65 (present-day location see Fig. 1), known as the Gondwana Fold Belt (GFB) or the Cape Fold Belt (CFB).

66 This fold-and-thrust-belt was reactivated during the Early Mesozoic as a strike-slip system before the

67 opening of the South Atlantic (Cobbold et al., 1992). During this reactivation it weakened the South

68 American plate prior to the development of the Atlantic Mid-Oceanic Ridge, forming a first set of

69 extensional basins (Autin et al., 2013), their axes oriented obliquely to the present-day orientation of the

70 spreading centre (Fig. 1). Several extensional pulses caused the opening of the South Atlantic between 134

71 Ma and 113 Ma (e.g. Torsvik et al., 2009; Moulin et al., 2010). Voluminous volcanic activity, recognised

72 on seismic reflection profiles as 'Seaward Dipping Reflectors' (SDR's) in the form of aerial flood basalts

73 (extrusive) and/or underplating (intrusive) accompanied an episode of extension that created the South

74 Segment (Fig. 1), starting between $134 \mathrm{Ma}$ and $132 \mathrm{Ma}$ (Moulin et al., 2010). Another pulse contributed to

75 the formation of the Central Segment, starting around $112 \mathrm{Ma}$ (Moulin et al., 2010) and is marked by

76 massive salt deposits that have not been found along the margins of the South Segment (Fig. 1, Torsvik et

77 al., 2009). Only minor volcanic activity has been recorded in this segment as the typical SDR's are mostly

78 absent, except just north of the Rio Grande Rise (Franke, 2013). The opening of the South Atlantic and 
79 formation of the Mid-Atlantic Ridge is considered to be due to a combination of passive far-field forces

80 (Husson et al., 2012) and the presence of different hotspots (Torsvik et al., 2009). A major far-field stress

81 component that enhanced the growth of the South Atlantic domain during the Mesozoic is the subducting

82 and 'pulling' Nazca plate to the west of the South American continent, which also resulted in the faster

83 west-ward migration of the South American plate with respect to the almost stationary African plate (e.g.

84 Husson et al., 2012). The South-African super plume rises from the core-mantle boundary (CMB) to below

85 the mantle transition zone (Hassan et al., 2015) which is reflected in present-day topography by a

86 "superswell" at the margins of the south-west African continent (Nyblade and Robinson, 1994; Davaille et

87 al., 2005). As shown by a.o. Lithgow-Bertelloni and Silver (1998), this excess of topography elevation is

88 dynamically supported by upwelling flow of buoyant material through the mantle. From this large-scale,

89 lower mantle low-velocity anomaly, the hotspots and their tracks (e.g. the Bouvet (Meteor), the Trinidad

90 and St Helena Hotspots (Torsvik et al., 2006,2009)) and the only deep rooted Tristan plume (Fig. 1, Torsvik

91 et al. (2009) and references therein) might develop over a long period of time ( 200 Myr).

\subsection{Lithosphere structure margins}

94 The selected profile for our 2D model connects the offshore southwest Africa Orange Basin and its conjugate with the Colorado basin on the South American side (pink line, Fig. 1). The Tristan hotspot lies actually in the middle of the two transects (Fig. 1). The present-day crustal and lithosphere structure of these

97 margins is constrained by combining published work on deep seismic refraction data, tomography, gravity 98 and magnetic studies (Fig. 2).

99 On the African side of the transect (Fig. 2a) the lithosphere thickness ranges from $120 \mathrm{~km}$ below the oceanic crust to $200 \mathrm{~km}$ below the continent (Fishwick, 2010). With gravity modelling and seismic interpretation the Moho-depth has been estimated to be less than $10 \mathrm{~km}$ below the oceanic crust of the Orange basin and over $40 \mathrm{~km}$ below the continent (Maystrenko et al., 2013). Even though crustal movements have been observed in central Africa, the southern African plate is considered relatively stable with a strong rheology

104 (Heine et al., 2013). 
On the South American side the lithosphere-asthenosphere boundary (LAB) reaches depths of 160km below the stable continent in Eastern Brazil and $120 \mathrm{~km}$ in below the continent in Central Argentina (Heit et al., 2007). The Moho depth varies between $70 \mathrm{~km}$ below the plateau in the Andean orogeny to $25-35 \mathrm{~km}$ below the flat continent (Van Der Meijde et al., 2013). For the Colorado basin specifically, deep refraction seismic studies reveal a crustal thickness of the margins of $30 \mathrm{~km}$ (Franke et al., 2006).

We assume that before continental break-up, the lithosphere thickness of the South American plate was similar to that of the African plate. However, the South American plate underwent an earlier deformation phase prior to the formation of the South Atlantic domain (Autin et al., 2013). Extensional deformation does result in lithospheric thinning and weakening (Ziegler and Cloetingh, 2004). We, therefore, adopt a weaker strength compared to the African plate and a thickness of $180 \mathrm{~km}$, which is the mean between the $200 \mathrm{~km}$ of the African lithosphere and the present-day $160 \mathrm{~km}$ South American lithosphere, to account for this earlier 116 deformation phase.

\subsection{High velocity/high density bodies and aborted rift structures}

Along the South Atlantic conjugate margins high velocity/high density bodies have been described at lower crustal depths below the continent and the margin (Fig. 1) using seismic data and gravity modelling. Anomalous gravity and velocity bodies have been noted in the Central segment on the African side from on the African side these bodies have been observed in the Walvis Basin (Blaich et al., 2011) and the Orange Basin (Dressel et al., 2015) and on the South American side in the Colorado basin, along the Uruguayan margin (Clerc et al., 2015) and in the deep Argentina Basin (Franke et al., 2006; Schnabel et al., 2008).

128 These bodies differ from the seaward-dipping reflectors (SDR) as they are situated at the base of the 129 lithosphere or at lower crustal levels and do not necessarily have a magmatic origin. They could be 130 serpentinized mantle or mafic and ultramafic crustal rocks (Fig. 2, Blaich et al., 2011). 
131 Graben structures or aborted rift structures onshore along the whole South American margin of the South 132 Atlantic domain (Burke, 1976), are located near the anomalously high velocity/high density bodies. In the 133 South Segment, graben structures and failed rift structures are less-abundant along the African margin, 134 where they appear mainly along the south South-African margin and in the Central segment along the Gabon 135 and Benin margins. On the South American side of the South Segment, the basins oriented perpendicular to 136 the present-day ridge extend onshore as aborted rift features (Burke, 1976). Another failed rift feature is 137 observed in the southwestern part of the Santos Basin, where the now aborted Abimael ridge is located 138 parallel to the present-day Mid Oceanic Ridge (Heine et al., 2013).

\section{Model setup}

141 The 2D thermo-mechanical numerical code FLAMAR, based on the FLAC-Para(o)voz algorithm (Cundall, 142 1989; Poliakov et al., 1993) has been used to investigate the effect of plume location on continental break143 up using the South-Atlantic as an example of a fully developed rift-to-spreading system. We built our case 144 on the continuation of earlier parametric studies on the rheology of the lithosphere and plume-continental 145 lithosphere interactions (D'Acremont et al., 2003; Burov et al., 2007). Where needed, we adjust the 146 parameters according to the geological and geophysical evidence described above. A symmetric simulation 147 that is not area-specific are carried out with the 3D viscous-plastic numerical code 3DELVIS (Gerya and 148 Yuen, 2007). All mechanical and thermo-rheological parameters are listed in Table 1. We have performed 149 a series of 36 experiments. Controlling parameters and principal results are summarized in Table 2.

\subsection{D numerical model}

152 The FLAMAR code has been updated and modified over the last 20 years (Burov and Diament, 1995; Burov 153 and Poliakov, 2001; Le Pourhiet et al., 2004; Yamato et al., 2008). For the sake of coherency with previously 154 published papers we only describe the main features and essentials of the model used for this study. Detailed 155 descriptions of the code can be found in studies that have tested the code for many different geological cases 156 (D'Acremont et al., 2003; Le Pourhiet et al., 2004; Yamato et al., 2008). FLAMAR is a fully explicit, finite 
element/finite difference code based on a Cartesian coordinate frame. It has a 2D strain formulation with a containing tri-linear shape functions. It uses a large-strain, time-marching scheme. The code solves for full Newtonian equations of motions in a continuum mechanics approximation (3.1)

$$
<\rho \ddot{\boldsymbol{u}}>-\nabla \sigma-\rho \boldsymbol{g}=0
$$

where $\rho, \ddot{\boldsymbol{u}}, \sigma$ and $\mathbf{g}$ stands for density, acceleration of the object, stress and acceleration due to body forces 163 or gravity, respectively.

164 It is coupled with constitutive laws (3.2) to quantify viscous, elastic and plastic characteristics by the heat transfer equation (3.3), where the heat advection term $(\dot{\boldsymbol{u}} \nabla T)$ is included in the Lagrangian derivative (DT/Dt). Erosion and sedimentation is accounted for using a linear diffusion equation assuming conversation of mass (3.4).

$$
\rho C_{p} D T / D t-k \nabla^{2} T-\sum_{i}^{n} H_{i}=0 ; \quad \rho=f(P, T)
$$

$$
\frac{d h}{d t}=a \nabla^{2} h
$$

171 In this case, $t$ stands for time, $\mathbf{u}$ is the displacement vector, and $T$ is temperature. The heat transfer equation 172 relies on $C_{p}$ for the specific heat, $k$ for thermal conductivity respectively and $H$ for the internal heat 173 production, including radiogenic heat and frictional heat dissipation. $P$ stands for pressure that become negative for compression. The linear diffusion equation uses a constant $a$ and the height or thickness of the 175 sediments $h$.

176 The code is capable of calculating realistic visco-elasto-plastic rheologies explicitly. Pressure-dependent deformation is maintained through the Mohr-Coulomb criteria for the plastic regime and the non-linear viscous flow law at depth. The free surface upper boundary condition calculates high-resolution topographic changes due to deformation of the lithosphere. 
The model box is $2000 \mathrm{~km}$ wide and $400 \mathrm{~km}$ deep. The grid size is $400 \mathrm{x} 80$ elements, resulting in a resolution of $5 \mathrm{~km}$ x $5 \mathrm{~km}$ per element. We have tested three different lithospheric setups with diverse complexities (see 3.1.2, Fig. 3) and three different locations of a $1700^{\circ} \mathrm{C}$ thermal and compositional mantle anomaly at $400 \mathrm{~km}$ depth (D'Acremont et al., 2003). The initial locations vary laterally at the base of the model with the center of the anomaly positioned 1) at the centre of the model (i.e. plume location at 1000 $\mathrm{km}$, see Table 2), 2) at $200 \mathrm{~km}$ to the right of the model box's centre (i.e. plume location at $1200 \mathrm{~km}$ ) and 3) at $200 \mathrm{~km}$ to the left of the model box's centre (i.e. plume location at $800 \mathrm{~km}$ ). Each location is tested in a separate calculation. Following previous studies the base of the anomaly lies at $400 \mathrm{~km}$ depth as the deeper mantle phase does not have a large impact on the crustal evolution (D'Acremont et al., 2003; Ribe and Christensen, 1994). The anomaly has a simplified, symmetric, spherical shape since at depth viscous bodies take a spherical shape and this follows the line of 2D and 3D numerical modelling experiments on plumelithosphere interaction (a.o. D’Acremont et al., 2003; Burov and Gerya, 2014; Koptev et al., 2016). In most of the experiments, it has a diameter of $230 \mathrm{~km}$. The effects of a mantle anomaly with a diameter of $100 \mathrm{~km}$ were tested in a limited number of models. The composition of the mantle anomaly is olivine with a density of $3250 \mathrm{~kg} / \mathrm{m}^{3}$ (except for several models where it is $3310 \mathrm{~kg} / \mathrm{m}^{3}$ ) which has been determined to be an intermediate plume in previous studies (Turcotte and Schubert, 2002; D'Acremont et al., 2003). No background density tests have been performed as the background density used for background calculations is the same for the plume as well as the surrounding mantle. The thermal contrast between the plume and the mantle varies as thermal exchanges happen between the plume and the mantle, decreasing the temperature of the plume. The mantle also cools as the plume rises to shallower depths.

\subsubsection{Density and rheological structure}

The 2D model consists of four horizontal rheological layers. For Setup 1 (Fig. 3a and Fig. 3b), a laterally homogeneous $40 \mathrm{~km}$ thick two-layered crust and a $160 \mathrm{~km}$ thick lithospheric mantle have been applied. We test the model's sensitivity for two different rheological properties of the crust. We use a "weaker" rheological strength envelope (Setup 1a; Fig. 3a), composed of 1) a wet quartz upper crust with a density of 

envelope has the characteristics of a "strong", cratonic crust that consists of: 1) a dry quartz upper crust with a density of $2600 \mathrm{~kg} / \mathrm{m}^{3}$ and 2) a strong diabase lower crust with a density of $2850 \mathrm{~kg} / \mathrm{m}^{3}$. The rheological differences of the two strength envelopes represent a "weaker" crust that has been subject to an earlier deformation phase, before the opening of the South Atlantic, which is the case for the South American side

213 (Autin et al., 2013), and a "stronger" crust of cratonic nature that represents the stable southern African 214 continent(after Burov and Diament, 1995). Dry olivine flow law has been assumed for both lithospheric and 215 sub-lithospheric mantle in all our experiments. The initial density of the mantle decreases from $3330 \mathrm{~kg} / \mathrm{m}^{3}$ 216 to $3310 \mathrm{~kg} / \mathrm{m}^{3}$ at the lithosphere-asthenosphere boundary. Specific values of the rheological parameters used 217 are given in Table 1.

218 For Setups 2 and 3 we apply a laterally non-homogeneous crustal rheology: a "weak" crustal rheology for 219 the left half of the model and a "strong" crustal rheology for the right one (Fig. 3c-f). The crustal and 220 lithospheric thicknesses are laterally homogeneous in Setup 2a: $20 \mathrm{~km}$ for upper crust, $20 \mathrm{~km}$ for lower crust 221 and $160 \mathrm{~km}$ for lithospheric mantle (Fig. 3c). Setups $2 \mathrm{~b}$ and 3 are characterized by laterally varying 222 lithospheric layers, based on the lithospheric scale structure described in section 2.2: the "weaker" left half 223 has a $15 \mathrm{~km}$-thick upper crust, $15 \mathrm{~km}$-thick lower crust and a $150 \mathrm{~km}$-thick lithospheric mantle, whereas the 224 "stronger" right half has a $20 \mathrm{~km}$-thick upper crust, a 20-km think lower crust and a $160 \mathrm{~km}$-thick 225 lithospheric mantle (Fig. 3c-f). Three different contacts between the rheological strengths are tested. Setup $2262 \mathrm{~b}$ has a straight vertical contact. For Setup 3 we have adopted a geometry resembling the old suture zone 227 that is reactivated during the first extensional phase. The suture is dipping either 40 degrees towards the 228 'strong', African rheology (Setup 3a) or towards the 'weak' South American rheology (Setup 3b).

229 By the setups described above we have tested the following parameters: initial position of the plume, density 230 of the mantle plume (limited to Setup 3a) and different half-rate velocity boundary conditions (see Table 1).

\subsubsection{Mechanical and thermo-rheological boundary conditions}


233 We simulate tectonic forcing by applying a constant, time independent, extension rate along the vertical side 234 of the box of $25 \mathrm{~mm} / \mathrm{yr}$. An equal half-rate velocity is applied on both sides of the box (12.5 mm/yr) to one 235 set of models and $5 \mathrm{~mm} / \mathrm{yr}$ on the right side and $20 \mathrm{~mm} / \mathrm{yr}$ on the left side is applied to a second set of 236 models (Table 1). The half-rate velocities are adopted from (Müller et al., 2008). The bottom of the box is 237 defined by hydrostatic pressure with free slip in all directions. The upper side of the box is a free surface 238 boundary, implying a free stress and a free slip condition in all direction, allowing the lithosphere to develop 239 freely. A moderate erosion by diffusion is applied $\left(a=500 \mathrm{~m}^{2} / \mathrm{yr}\right)$.

240 The upper and bottom thermal boundary condition is a fixed temperature $10{ }^{\circ} \mathrm{C}$ and $1400{ }^{\circ} \mathrm{C}$ respectively to 241 represent a 'cold' geotherm. An old lithosphere of $500 \mathrm{Ma}$ (Burov and Diament, 1995) has been assumed

242 for the tectonic age used to represent the super-continent Pangea before break-up. The geotherm used for 243 the models reaches $500{ }^{\circ} \mathrm{C}$ at Moho depth, $1330{ }^{\circ} \mathrm{C}$ at the lithosphere-asthenosphere boundary (LAB) after 244 which it becomes adiabatic until it reaches $1400{ }^{\circ} \mathrm{C}$ at the base of the model at $400 \mathrm{~km}$ (Ribe and Christensen, 245 1994).

\section{2. $3 D$ numerical model}

248 A 3D model has been performed with the thermo-mechanical viscous-plastic 3DELVIS code (Gerya, 2010; 249 Gerya and Yuen, 2007) that combines the finite difference method with a marker-in-cell technique. The 3D 250 model box has the horizontal dimensions $1500 \times 1500 \times 635 \mathrm{~km}$ and consists of $297 \times 297 \times 133$ nodes

251 offering spatial resolution of ca. $5 \times 5 \times 5 \mathrm{~km}$ per grid cell. Not area-specific initial setup consists of a 252 stratified three-layer (upper/lower crust and lithospheric mantle) continental lithosphere underlain by an 253 asthenosphere. The total thickness of the two-layer crust is $36 \mathrm{~km}$; the depth of lithosphere-asthenosphere 254 boundary is $150 \mathrm{~km}$. The mantle plume has been seeded at the base of the modelled domain by a spherical 255 thermal anomaly of $370{ }^{\circ} \mathrm{C}$ with a radius of $200 \mathrm{~km}$. The initial geotherm is piece-wise linear with fixed 256 temperatures at the surface $\left(0^{\circ} \mathrm{C}\right)$, at the Moho $\left(700^{\circ} \mathrm{C}\right)$, at the base of the lithosphere $\left(1300^{\circ} \mathrm{C}\right)$, and at the 257 bottom of the model box $\left(1630^{\circ} \mathrm{C}\right)$. Weak tectonic forcing has been simulated by applying a constant ultra258 slow divergent horizontal velocity of $3 \mathrm{~mm} /$ year along the sides of the model. More detailed information on 
the 3D model setup and rheological and material properties used in our 3D experiments can be found in

260 Burov and Gerya (2014) and Koptev et al. (2015, 2016).

\section{Model results}

\section{1. $2 D$ model results}

264 Three types of model scenarios result from our set of experiments. "Centred" break-up, when the mantle 265 anomaly moves vertically upwards and break-up happens directly above the original location of the centre 266 of the mantle anomaly. "Shifted" break-up, when the mantle anomaly first migrates vertically and, once it 267 reaches the base of the lithosphere, migrates laterally until break-up occurs with a 50 to $250 \mathrm{~km}$ offset with 268 respect to the initial anomaly position. "Distant" break-up, when a mantle anomaly rises to the base of the 269 lithosphere and remains there, while the location of break-up takes place more than $300 \mathrm{~km}$ away from the 270 initial site of the anomaly.

271 Experiment 6, characterized by a "strong" homogenous lithosphere, is an example of "centred" break-up 272 (Fig. 4a). The mantle anomaly reaches the base of the lithosphere rapidly within 2 Myr, after which it 273 penetrates into the lithosphere. The rising flow of plume material is strong enough to break apart the 274 overlying lithospheric mantle and crust between 7 and 8 Myr. The surface reacts by uplift, then subsidence 275 and alternating positive and negative vertical movements of the margins and the rift centre. Although the 276 initial position of break-up centre is situated directly above mantle plume, the continuous extensional 277 evolution, including strain relocation and changing temperature distribution, suggest a post-rift lateral shift 278 of the spreading axis. Note that after continental break-up mantle plume material reaches the surface where 279 it contributes to the formation of new oceanic lithosphere.

280 The "shifted" mode of continental break-up is illustrated by Experiment 12 where the mantle plume anomaly 281 has been seeded below a stronger lithosphere composing the right half of the model domain (Fig. 4b). As in 282 the case of Experiment 6, the onset of rifting starts with a rapid rise of the anomaly, impinging the 283 lithosphere not later than 2 Myr. Surface topography associated with localized crustal strain is formed 284 around 3-4 Myr with small offset $(<50 \mathrm{~km})$ from the point directly above mantle plume impingement. 
285 Further upslope migration plume material leads to continental break-up between 7 and 10 Myr. A principal difference from the "centred" experiment 6 is the lateral shift (50 to $250 \mathrm{~km}$ ) of the newly formed spreading axis with respect to the initial position of the mantle plume. Lateral migration of the plume head to this break-up axis leads to an asymmetrical distribution of the plume material: some of the material reaches the surface at the spreading centre, another part remains glued beneath the highly thinned lithosphere at depths between 200 and $10 \mathrm{~km}$. Similar to Experiment 6, the final stage of the "shifted" system development is the strain relocation corresponding to $200 \mathrm{~km}$-wide jump of the spreading axis.

292 Finally, experiment 16 illustrates the "distant" break-up mode that starts with a rapid uplift of the mantle 293 plume to the bottom of the lithosphere, an observation typical for all performed models. This expectedly 294 results in associated topography variations (Fig. 4c). In contrast with the two previously discussed break-up 295 modes (experiments 6 and 12), mantle plume material remains glued beneath the base of the lithosphere 296 without localized ascent towards the formed break-up centre. Lithosphere thinning that will result in break297 up occurs at large distance (more than $500 \mathrm{~km}$ ) from the plume impingement. This appears to be related to secondary mantle convection associated with plume-induced subduction of the lithospheric mantle that has developed upon plume upwelling to the lithosphere-asthenosphere boundary on both sides of the plume head. It is noteworthy that initial topographic changes created by the impingement of the plume remain visible throughout the model evolution. Given the lack of near-surface plume material, this "distant" mode cannot be considered as break-up directly induced by the impact of the mantle plume. Nevertheless, it might reflect the implicit influence of the upwelled plume on "distant" break-up processes via plume-induced subduction and mantle convection.

"Centred" break-up preferably takes place using initial Setup 1, where the crust and lithospheric mantle are laterally homogeneous and no inherited structures are given (Fig. 4a, Table 1), but other setups can also evolve according to this mode (Fig. 5a-c). Break-up occurs between 6 and $10 \mathrm{Myr}$, directly above the initial location of the mantle anomaly. Mantle material reaches the surface at the point of impingement that evolves into the break-up axis. Almost all plume material is involved in formation of new oceanic lithosphere. As a result, after continuous (more than $10 \mathrm{Myr}$ ) calculations, only little material remains below the thinned 
311 continental lithosphere. Note that, even though central located plumes are expected to develop to a 312 symmetric or "central" mode, a central located plume evolves the least likely into "central" type of break313 up (table 1). "Shifted" break-up is favoured by Setup 2a where the thickness of the lithospheric layers is 314 laterally homogeneous but crustal rheology differs (Fig. 5d-f). The mantle anomaly rises and break-up also 315 occurs between 6 and $10 \mathrm{Myr}$, but in this case it is shifted from the initial point of impingement. Most mantle 316 material remains below the lithosphere, but through migration along the bottom of the lithosphere some 317 material still reaches the surface. This mode of break-up only occurs when the lithosphere properties 318 (rheology and/or thickness) varies laterally, but it does not completely control "shifted" break-up, because 319 not all laterally varying rheology experiments result in "shifted" break-up. Plume location is also not a 320 controlling factor for the model to result in "shifted" break-up as all three plume locations can result in 321 "shifted" break-up. The "distant" break-up experiments have a preference for Setup 2 and 3, where both the 322 lithospheric layers' thickness and the crustal rheology are laterally different (Fig. 5g-i). Crustal break-up 323 happens slightly later compared to the "centred" and "shifted" experiments: between 9 and 12 Myr. Mantle 324 anomaly material does not reach the surface, but remains completely glued to the bottom of the lithosphere. 325 Most of the continental break-up modelled with the "distant" experiments occurs in the lithospheric segment 326 that is characterized by a strong crust.

327 Almost half (12 out of 25) of the equal half-rate velocities boundary condition results in "centred" breakup. More than half (6 out of 11) of the unequal half-rate velocity boundary conditions result in "distant" 329 break-up mode. The different velocity parameters do have a preference for a certain break-up style, but it is 330 not a controlling factor.

331 The models that resulted in "shifted" break-up have a mantle anomaly that rises to the base of the lithosphere 332 and upon arrival, migrates, in most cases, towards the weaker lithosphere to break through this less strong 333 segment. This is in contrast with the "distant" model results that develop crustal break-up in the stronger 334 lithosphere (11 out of 11 models) when the plume remains glued below the weaker lithosphere and does not 335 break through. In case of "distant" break-up mode, the rheology is very important and strongly controls this 336 mode of break-up. 


\section{2. $3 D$ model results}

339 Similarly to the 2D experiments, the 3D model shows a quick ( $<2 \mathrm{Myr}$ ) upwelling of the plume material up 340 to lithosphere-asthenosphere boundary (Fig. 6a). After this, the plume head starts to spread laterally within 341 lower part of lithospheric mantle (Fig. 6b-d). When the mantle plume impinges on the base of lithosphere, 342 almost all plume material is partially melted (Fig. 6a). Following spreading and cooling expectedly leads to 343 gradual solidification of the plume (Fig. 6b-c), which has been completed at $50 \mathrm{Myr}$ (Fig. 6d).

344 The interplay between far-field forces and active mantle upwelling results in a "classical" single rift that 345 crosses the entire model domain in the direction perpendicular to external extension (Fig. 6a). Continuous 346 evolution shows the formation of a wide rift valley where localized brittle deformation is concentrated along 347 the boundary fault (Fig. 6b-c). This rift basin opens rapidly (Fig. 6b) reaching a width of $600 \mathrm{~km}$ in less than $34835 \mathrm{Myr}$ while passive extension applied at the boundaries would result in only $200 \mathrm{~km}$ width (Fig. 6c). This 349 highlights the important role of plume-related buoyancy forces in the context of studied "active-passive" 350 rifting.

351 The next stage of the system evolution (65 Myr) is a quick switch of deformation localization from rift352 bounding faults to narrow zones inside the rift valley (Fig. 6e). This change in rifting style is caused by 353 initiation of localized upwelling of plume material along stretched zone(s) highlighted at the surface by 354 localized high strain rates (Fig. 6e). Further localized plume ascent associated with decompression melting 355 of plume material increases the rate of lithospheric thinning leading to continental break-up along a 356 spreading axis that has shifted laterally outwards from the centre of the plume head (Fig. 6f). This 357 asymmetrical position of the spreading zone arises spontaneously within initially symmetrical and laterally 358 homogenous lithosphere and is likely controlled by melting and cooling processes into head of mantle 359 plume.

360 Thus, a lateral shift of plume-induced break-up centres with respect to initial plume impingement revealed 361 in certain 2D experiments (see for example Experiment 6, Fig. 4a) appears to be an intrinsic characteristic 362 of self-induced plume-related processes that do not necessary requires fast ( $>1 \mathrm{~cm} / \mathrm{y})$ external extension nor 
any lateral lithospheric heterogeneity (see also Experiment 2 for a 2D example of "distant" break-up in the 364 context of laterally homogenous lithosphere).

\section{Discussions}

\subsection{General aspects}

368 The results of our models are important in the context of ongoing discussion on plume-induced continental

369 break-up. We show that continental break-up can be initiated by just one single mantle plume under different 370 initial and boundary conditions. In most of our 2D models (32 out of 36) continental break-up takes place 371 as a result of the direct ("centred" or "shifted" modes) or indirect ("distant" mode) impact of the mantle 372 plume (Fig. 8). Four remaining models do not result in break-up. On one hand, the models that develop 373 according to "centred" (Fig. 8b) or "shifted" (Fig. 8c) modes are directly induced by the plume anomaly 374 which results in penetration of plume material up to the surface. On the other hand, the "distant" mode is 375 characterized by secondary mantle convection associated with plume-induced subduction and/or 376 convection. In this case, the mantle plume is not involved directly in break-up processes and remains glued 377 at the base of adjacent unbroken lithosphere (Fig. 8d).

378 In a very early phase, strain rate localizes and topographic variations develop directly above the initial plume 379 impingement location (Fig. 8a). They remain visible only in the "shifted" and "distant" models and can be 380 interpreted as aborted rifts. It was commonly accepted and almost self-evident that in the case of plume381 induced continental break-up, its axis should be situated directly above the initial plume impingement 382 position (D’Acremont et al., 2003). However, observations such as failed rifts and deep-seated mantle 383 sources beneath a strong continent that are significantly remote from the mid-oceanic ridge, actually imply 384 that continental rifting and break-up are not a purely symmetric and "plume-centred" processes. Our 385 modelling demonstrates that symmetric development of mantle material ascent and subsequent continental 386 break-up are not a definite outcome. More than half of our models (19 out of 32) result in "shifted" and

387 "distant" break-up modes, suggesting that these modes should also be expected in a wide range of initial 388 and boundary conditions. Even so, our perfectly symmetric and lateral homogeneous 3D model shows that 
in a purely symmetric setting, with no lithospheric rheological heterogeneities, continental break-up shifted from the original centre of the mantle anomaly is possible. We argue here that "centred" symmetric continental break-up developed directly above mantle plume is only one particular case of possible evolutions of plume-induced break-up systems.

\subsection{The case of the South Atlantic}

The South Atlantic is considered to be a good example of plume-induced continental break-up (e.g. Torsvik et al., 2009). Some of the observations such as failed rifts (Heine et al., 2013) and high velocity bodies (e.g. Blaich et al., 2011) cannot be explained with conventional models, usually assuming a "centred"-like breakup style (e.g. Burov et al., 2007; D'Acremont et al., 2003). Yet, our experiments showing "shifted" breakup mode (Fig. 7; Fig. 8c) can be used to explain these features. In these models, initial crustal deformation associated with mantle plume impingement (Fig.7a-b; Fig.8a) are formed within the first 5 Myr. Significant 401 topography variations developed during this initial stage of rift evolution (i.e. before break-up) can be interpreted as very early failed rift features (e.g. the failed Abimael rift in the southwest of the Santos Basin).

403 The topographic plateaus that remain elevated long after break-up have also been observed with dynamic topography studies (Nyblade and Robinson, 1994). Next, localized strain becomes concentrated close to the boundary between strong and weak lithosphere that is laterally offset ( $400 \mathrm{~km})$ from the area of initial plume impingement (Fig.7c). Transition from wide rift stage to lithospheric break-up is marked by narrowing a broad rift region (over $1000 \mathrm{~km}$ width) down to narrow rift valley (Fig. 7c-d) with the width of 408 10's of kilometers between the two rift-shoulders. Associated lithospheric thinning leads to a separation of 409 the two plates along a spreading centre corresponding to South Atlantic ridge (Fig.7e; Fig.8c). Part of strong 410 crust that remains attached to the weaker lithosphere segment, could correspond to the Brazilian craton that 411 was once bordering the African continent (Heine et al., 2013).

412 Simultaneously with thinning of the lithosphere below the future break-up centre, the plume material 413 migrates along the base of the lithosphere and rises towards the deformed crust where it breaks through. 414 This migration can go as far as $300 \mathrm{~km}$ from the plume impingement point and only ceases when the material 
416 (in this case after $22 \mathrm{Myr}$ ). This confirms the hypothesis that one mantle anomaly (or plume) can flow

417 laterally over significant distances below a slow-moving continent, after being risen to the base of the

418 lithosphere (e.g. Sleep, 2006). When thermal equilibrium is reached, the mantle material glued to the base

419 of the lithosphere at shallower depths corresponds geometrically and location-wise to high-velocity/high-

420 density bodies observed on seismic data below the thinned continental lithosphere and the transition zone

421 of the South Atlantic domain (Clerc et al., 2015). During migration, products of partial melting of the mantle

422 material can move vertically to (shallow) lower crustal levels. They might resemble high density bodies

423 observed at lower crustal levels inside continental crust with similar geometries observed with gravity

424 modelling (Blaich et al., 2011). These processes cannot be reproduced by our 2D modelling, because no

425 melt production and extraction have been simulated.

426 Note that our 2D study has not the intention to capture such 3D features like along-axis northward 427 propagation of the break-up axis (Franke, 2013) up to the centre of the surface manifestation of Tristan 428 plume activity - the Paraná-Etendeka continental flood basalts province.

429 After continental break-up, the mantle plume anomaly continues to play an important role in the spreading 430 evolution of the system. Strain rate relocation takes place around $18 \mathrm{Myr}$, when the spreading axis shifts 431 another $200 \mathrm{~km}$ towards the left from the original position of the break-up centre (Fig. 7f). This phenomenon 432 could correspond to a rift-jump that have also been both observed and modelled (Brune et al., 2014) in the 433 South Atlantic domain.

434 The question we raised about the initial position of the mantle plume anomaly responsible for continental 435 break-up in the South Atlantic remains open. On figure 8e, we show a reconstructed configuration of the 436 slow velocity anomaly (corresponding to the South African Super Plume) at the CMB based on present-day 437 seismic tomography model (after Davaille et al., 2005). The orange dots refer to the three possible principal 438 locations of initial thermal anomaly at the upper/lower mantle boundary corresponding to the Tristan plume. 439 The central point refers to the most evident "centered" scenario (Fig. 8b) when the deep-seated thermal 440 anomaly in the upper mantle is supposed to be located directly below its surface manifestation and hints to 
441 voluminous Paranà-Etendeka continental flood basalts province (Fig. 8e, e.g. Torsvik et al., 2009; Heine et 442 al., 2013). This scenario, however, is not consistent with the commonly considered concept that plumes 443 emerge from the edges of the large low-velocity anomalies at the CMB that has been confirmed by both 444 numerical modelling (Hassan et al., 2015) and by empirically established correlation between downward 445 projected plume-associated large igneous provinces and the margins of the large low shear velocity province 446 beneath Africa (Torsvik et al., 2006). Moreover, with this 'centred' scenario we cannot explain additional 447 features such as failed rift arms and anomalous bodies at lower crustal levels. The 'distant' break-up mode 448 (Fig. 8d), where the initial plume centre is located below the South American section and remains there after 449 "plume-independent" continental break-up, does not fit well with geological observations of the voluminous 450 Paranà-Etendeka continental flood basalts that are supposed to be related with direct influence of the Tristan 451 hot spot (Torsvik et al., 2009). Finally, initial plume position slightly moved to African side (right dot on 452 Fig. 8e) refers to "shifted" scenario that seems to be preferable (Fig.8c). The time length of the modelled 453 rift phase (10 Myr +/- $3 \mathrm{Myr})$ is much shorter than has been inferred from geological and geophysical 454 observations (160 Ma to 134 Ma, (Franke, 2013)) in the South Segment of the South Atlantic. Despite this, 455 with the eastward offset initial position of the mantle plume with respect to a heterogeneous thermo456 rheological lithospheric structure we are able to explain not only plume induced flood basalts but also a set 457 of anomalous features such as failed rift systems, and deep crustal bodies.

\section{Conclusion}

460 Different lithospheric strengths comparable to the South American and African continental crust, inherited 461 structures, boundary velocity conditions corresponding to average spreading rates, and initial location of a 462 thermal mantle anomaly (i.e. plume) have been tested to investigate the dynamics of plume induced 463 continental break-up. A set of 36 models shows that with only one anomaly three very different scenarios 464 for continental break-up can be realized depending on the rheological structure, anomaly location and 465 inherited structures. Continental break-up does not necessarily occur above the centre of the initial location 
of a mantle anomaly. As mentioned above, our models show three types of break-up 1) "centred” break-up, 2) “shifted” break-up and 3) "distant” break-up.

"Centred" and "shifted" break-up types of models refer to plume-induced type of break-up. For the first mode, mantle material rises vertically towards the bottom of the lithosphere after which it breaks through

470 the crust and reaches the surface directly above the initial plume position. The "shifted" type of break-up

471 shows continental break-up that is 50 to $200 \mathrm{~km}$ shifted from the initial location of the mantle anomaly. In

472 this case, the mantle plume rises and impinges the lithosphere, after that it migrates laterally and cuts through

473 the lithosphere reaching the surface at a break-up point considerably shifted from the area of initial, pre-

474 break-up impingement. Some material remains glued underneath the lithosphere at depths between 200 and

$47510 \mathrm{~km}$. These deep-seated bodies, at depths of $200 \mathrm{~km}$, are not situated directly below the break-up centre,

476 but are spread over a large area below the continental margins. The shallower bodies geometrically resemble

477 high density/high velocity bodies detected by seismic profiling and gravity modelling along the margins of 478 the South Atlantic domain and at lower crustal levels.

479 The "distant" break-up mode refers to continental rupture that is indirectly induced by the presence of the mantle plume ponding at the bottom of the weaker continental lithosphere, when "plume-independent" break-up of adjacent stronger lithosphere appears to be considerably (from 250 and $800 \mathrm{~km}$ ) displaced from the location of plume-lithosphere interaction. In this case, laterally widely spread plume material remains 483 glued below unbroken segments of the lithosphere.

484 Topographic changes that occur very early during initial rifting stage remain visible for a long period and can possibly be interpreted as failed rift systems (in the cases of "shifted" and "distance" modes). Strain 486 relocation after continuous post-break-up extension could be interpreted as rift jumps. A simple 3D model 487 has been built to illustrate that even in a fully symmetric setup, rift-to-break-up processes are not by default 488 symmetric and can very well evolve asymmetrically.

489 There is no controlling parameter for one of the three types of rifting, with a combination of parameters 490 determining the outcome, but the location of the mantle anomaly with respect to the rheology is the most 
essential. The most important result of this study is that there is not one single rift mode for plume-induced crustal break-up.

\section{Acknowledgment}

495

This study is co-funded by the Advanced ERC Grant 290864 RHEOLITH to A. Koptev and E.Burov. 3D 496 numerical simulations were performed on the ERC-funded SGI Ulysse cluster of ISTEP. We thank William Sassi (IFPEn), Xavier Guichet (IFPEn) and Sylvie Leroy (UPMC) for fruitful discussions in the early phases of the project. We would also like to thank Sierd Cloetingh (Utrecht University) for constructive and thorough reading of the manuscript. The two anonymous reviewers are also thanked for their helpful remarks and critical points of view.

\section{References}

Autin, J., Scheck-Wenderoth, M., Loegering, M.J., Anka, Z., Vallejo, E., Rodriguez, J.F., Dominguez, F., evolution, Argentine passive margin. Tectonophysics 604, 264-279. doi:10.1016/j.tecto.2013.05.019

Blaich, O.A., Faleide, J.I., Tsikalas, F., 2011. Crustal breakup and continent-ocean transition at South Atlantic conjugate margins. J. Geophys. Res. 116, 1-38. doi:10.1029/2010JB007686

Brune, S., Heine, C., Pérez-Gussinyé, M., Sobolev, S. V, 2014. Rift migration explains continental margin asymmetry and crustal hyper-extension. Nat. Commun. 5, 1-9. doi:10.1038/ncomms5014

Burke, K., 1976. Development of graben associated with the initial ruptures of the Atlantic Ocean. Tectonophysics 36, 93-112.

Burov, E., Gerya, T., 2014. Asymmetric three-dimensional topography over mantle plumes. Nature 513, 85-89. doi:10.1038/nature13703

Burov, E., Guillou-Frottier, L., D’Acremont, E., Le Pourhiet, L., Cloetingh, S., 2007. Plume headlithosphere interactions near intra-continental plate boundaries. Tectonophysics 434, 15-38. 
517 Burov, E., Poliakov, A., 2001. Erosion and rheology controls on synrift and postrift evolution: Verifying old and new ideas using a fully coupled numerical model. J. Geophys. Res. 106, 16461-16481.

Burov, E.B., Diament, M., 1995. The effective elastic thickness (Te) of continental lithosphere: What does it really mean? J. Geophys. Res. 100, 3905-3927. doi:10.1029/94JB02770

Clerc, C., Jolivet, L., Ringenbach, J.C., 2015. Ductile extensional shear zones in the lower crust of a passive margin. Earth Planet. Sci. Lett. 431, 1-7. doi:10.1016/j.eps1.2015.08.038

Cloetingh, S., Burov, E., Matenco, L., Beekman, F., Roure, F., Ziegler, P.A., 2013. The Moho in extensional tectonic settings: Insights from thermo-mechanical models. Tectonophysics $609,558-$ 604. doi:10.1016/j.tecto.2013.06.010

Cobbold, P.R., Gapais, D., Rossello, E.A., Milani, E.J., Szatmari, P., 1992. Permo-Triassic intracontinental deformation in SW Gondwana. Invers. Tectonics Cape Fold Belt, Karoo Cretac. Basins South. Africa 23-26.

Contrucci, I., Matias, L., Moulin, M., Géli, L., Klingelhofer, F., Nouzé, H., Aslanian, D., Olivet, J.L., Réhault, J.P., Sibuet, J.C., 2004. Deep structure of the West African continental margin (Congo, Zaïre, Angola), between $5^{\circ} \mathrm{S}$ and $8^{\circ} \mathrm{S}$, from reflection/refraction seismics and gravity data. Geophys. J. Int. 158, 529-553. doi:10.1111/j.1365-246X.2004.02303.X

Cornwell, D.G., Mackenzie, G.D., England, R.W., Maguire, P.K.H., Asfaw, L.M., Oluma, B., 2006. Northern Main Ethiopian Rift crustal structure from new high-precision gravity data. Geol. Soc. London, Spec. Publ. 259, 307-321. doi:10.1144/GSL.SP.2006.259.01.23

Cundall, P.A., 1989. Numerical experiments on localization in frictional materials. Ingenieur-Archiv 59, $148-159$.

D’Acremont, E., Leroy, S., Burov, E.B., 2003. Numerical modelling of a mantle plume: the plume headlithosphere interaction in the formation of an oceanic large igneous province. Earth Planet. Sci. Lett. 206, 379-396. doi:10.1016/S0012-821X(02)01058-0 
542 Davaille, A., Stutzmann, E., Silveira, G., Besse, J., Courtillot, V., 2005. Convective patterns under the 543 Indo-Atlantic «box ». Earth Planet. Sci. Lett. 239, 233-252. doi:10.1016/j.eps1.2005.07.024

544 Dressel, I., Scheck-Wenderoth, M., Cacace, M., Lewerenz, B., Götze, H.-J., Reichert, C., 2015.

545 Reconstruction of the southwestern African continental margin by backward modelling. Mar. Pet.

$546 \quad$ Geol. 67, 544-555. doi:10.1016/j.marpetgeo.2015.06.006

547 Dupré, S., Bertotti, G., Cloetingh, S., 2007. Tectonic history along the South Gabon Basin: anomalous

548 early post-rift subsidence. Mar. Pet. Geol. 24, 151-172. doi:10.1016/j.marpetgeo.2006.11.003

549 Fishwick, S., 2010. Surface wave tomography: Imaging of the lithosphere - asthenosphere boundary

550 beneath central and southern Africa? Lithos 120, 63-73. doi:10.1016/j.lithos.2010.05.011

551 Franke, D., 2013. Rifting, lithosphere breakup and volcanism : Comparison of magma-poor and volcanic

552 rifted margins. Mar. Pet. Geol. 43, 63-87. doi:10.1016/j.marpetgeo.2012.11.003

553 Franke, D., Neben, S., Schreckenberger, B., Schulze, A., Stiller, M., Krawczyk, C.M., 2006. Crustal

554 structure across the Colorado Basin, offshore Argentina. Geophys. J. Int. 165, 850-864.

$555 \quad$ doi:10.1111/j.1365-246X.2006.02907.x

556 Gerya, T., 2010. Dynamical instability produces transform faults at mid-ocean ridges. Science (80-. ). 329,

557 1047-1050.

Gerya, T. V, Yuen, D.A., 2007. Robust characteristics method for modelling multiphase visco-elastoplastic thermo-mechanical problems. Phys. Earth Planet. Inter. 163, 83-105. doi:10.1016/j.pepi.2007.04.015

Hassan, R., Flament, N., Gurnis, M., Bower, D.J., Müller, M., 2015. Geochemistry, Geophysics, Geosystems. Geochemistry Geophys. Geosystems 18, 1541-1576. doi:10.1002/2014GC005684.Key

Heine, C., Zoethout, J., Müller, R.D., 2013. Kinematics of the South Atlantic rift. Solid Earth 4, 215-253. doi:10.5194/se-4-215-2013

Heit, B., Sodoudi, F., Yuan, X., Bianchi, M., Kind, R., 2007. An S receiver function analysis of the lithospheric structure in South America. Geophys. Res. Lett. 34, 1-5. doi:10.1029/2007GL030317

567 Hirsch, K.K., Scheck-Wenderoth, M., Wees, J.-D. Van, Kuhlmann, G., Paton, D.A., 2010. Tectonic 
subsidence history and thermal evolution of the Orange Basin. Mar. Pet. Geol. 27, 565-584. doi:10.1016/j.marpetgeo.2009.06.009

Husson, L., Conrad, C.P., Faccenna, C., 2012. Plate motions, Andean orogeny, and volcanism above the South Atlantic convection cell. Earth Planet. Sci. Lett. 317-318, 126-135.

572 Koptev, A., Burov, E., Calais, E., Leroy, S., Gerya, T., Guillou-Frottier, L., Cloetingh, S., 2016.

573 Contrasted continental rifting via plume-craton interaction: Applications to Central East African Rift.

$574 \quad$ Geosci. Front. 7, 221-236. doi:10.1016/j.gsf.2015.11.002

575 Koptev, A., Calais, E., Burov, E., Leroy, S., Gerya, T., 2015. Dual continental rift systems generated by

576 plume - lithosphere interaction. Nat. Geosci. 8, 388-392. doi:10.1038/NGEO2401

577 Le Pourhiet, L., Burov, E., Moretti, I., 2004. Rifting through a stack of inhomogeneous thrusts (the dipping pie concept). Tectonics 23, 1-14. doi:10.1029/2003TC001584

579 Lithgow-Bertelloni, C., Silver, P., 1998. Dynamic topography, plate driving forces and the African superswell. Nature 395, 345-348. doi:10.1038/26212

Maystrenko, Y.P., Scheck-Wenderoth, M., Hartwig, A., Anka, Z., Watts, A.B., Hirsch, K.K., Fishwick, S., 2013. Structural features of the Southwest African continental margin according to results of lithosphere-scale 3D gravity and thermal modelling. Tectonophysics 604, 104-121.

Mohriak, W.U., Mello, M.R., Vieira, I.S., Bassetto, M., Koutsoukos, E.A.M., 2000. Crustal architecture, sedimentation, and petroleum systems in the Sergipe-Alagoas Basin, Northeastern Brazil. AAPG Spec. Vol. 273-300.

Moulin, M., Aslanian, D., Unternehr, P., 2010. A new starting point for the South and Equatorial Atlantic Ocean. Earth-Science Rev. 98, 1-37. doi:10.1016/j.earscirev.2009.08.001 of the world's ocean crust. Geochemistry, Geophys. Geosystems 9, 1-19. doi:10.1029/2007GC001743

Nyblade, A.A., Robinson, S.W., 1994. The African Superswell. Geophys. Res. Lett. 21, 765-768. 
Poliakov, A.N.B., Podladchikov, Y., Talbot, C., 1993. Initiation of salt diapirs with frictional overburdens: numerical experiments. Tectonophysics 228, 199-210. doi:10.1016/0040-1951(93)90341-G

Ranalli, G., 1995. Rheology of the Earth, 2nd edition. Chapmann and Hall, 413 pp.

Ribe, N.M., Christensen, U.R., 1994. Three-dimensional modeling of plume-lithosphere interaction. J. Geophys. Res. 99, 669-682.

Sandwell, D.T., Smith, W.H.F., 2009. Global marine gravity from retracked Geosat and ERS-1 altimetry: Ridge segmentation versus spreading rate. J. Geophys. Res. Solid Earth 114, 1-18.

Sleep, N.H., 2006. Mantle plumes from top to bottom. Earth-Science Rev. 77, 231-271. doi:10.1029/2008JB006008

Schnabel, M., Franke, D., Engels, M., Hinz, K., Neben, S., Damm, V., Grassmann, S., Pelliza, H., Dos doi:10.1016/j.earscirev.2006.03.007

Torsvik, T.H., Rousse, S., Labails, C., Smethurst, M.A., 2009. A new scheme for the opening of the South

Torsvik, T.H., Smethurst, M.A., Burke, K., Steinberger, B., 2006. Large igneous provinces generated from the margins of the large low-velocity provinces in the deep mantle. Geophys. J. Int. 167, 1447-1460. doi:10.1111/j.1365-246X.2006.03158.x

Tsenn, M.C., Carter, N.L., 1987. Upper limits of power law creep of rocks. Tectonophysics 136, 1-26. doi:10.1016/0040-1951(87)90332-5

Turcotte, D.L., Schubert, G., 2002. Geodynamics. Cambridge Univ. Press, Cambridge, UK.

Van Der Meijde, M., Julià, J., Assumpção, M., 2013. Gravity derived Moho for South America.

618 Yamato, P., Burov, E., Agard, P., Le Pourhiet, L., Jolivet, L., 2008. HP-UHP exhumation during slow 619 continental subduction: Self-consistent thermodynamically and thermomechanically coupled model 
622 Ziegler, P.A., Cloetingh, S., 2004. Dynamic processes controlling evolution of rifted basins. Earth-Science

623 Rev. 64, 1-50. doi:10.1016/S0012-8252(03)00041-2

624 
627 Figure 1. Map of the South Atlantic domain with the location of large fracture zones, high velocity bodies 628 (red ellipsoids), onshore graben structures (black dashed lines), the outline of the African Super Plume 629 (dashed green line, after Davaille et al. (2015)) and the African superswell (dashed red line, after Nyblade 630 and Robinson, 1994). Also shown are the extent of the Seaward Dipping Reflectors (SDR's, blue after 631 Moulin et al., 2010 and green after Torsvik et al., 2009) and the Aptian salt (yellow, after Torsvik et al., 632 2009) deposits. The orange line gives the location of the Gondwana Fold-and-Thrust-Belt. Pink solid lines 633 mark locations of the lithosphere-scale cross-sections (South America: A-A'; South Africa: B-B', Fig. 2). 634 Hotspots (red stars): $\mathrm{Tr}=$ Trinidad hotspot; $\mathrm{StH}=$ Saint Helena hotspot; Bv = Bouvet (Meteor) hotspot; 635 Deep-rooted mantle plume (yellow star): $\mathrm{TdC}=$ Tristan deep-rooted hotspot.

637 Figure 2. Lithosphere scale cross-sections of present-day South Atlantic margins. The Moho depth varies 638 from 10 to $30 \mathrm{~km}$ on the South American side from ocean to continent (Schnabel et al., 2008). On the 639 African side the depth varies from less than $10 \mathrm{~km}$ to over $40 \mathrm{~km}$, ocean to continent (Maystrenko et al., 640 2013). The lithosphere-asthenosphere boundary (LAB) varies from $50 \mathrm{~km}$ to $120 \mathrm{~km}$, ocean to continent for 641 Colorado basin on the Argentinean margin (Heit et al., 2007). The Orange Basin on the South African 642 margin has a LAB depth ranging between $80 \mathrm{~km}$ and $200 \mathrm{~km}$ from ocean to continent (Fishwick, 2010). The 643 location of anomalous bodies is depicted (in green) for the Colorado Basin (Schnabel et al., 2008) and the 644 Orange Basin (Maystrenko et al., 2013). The gravity profile has been extracted from the global marine 645 gravity map of Sandwell and Smith v18.1 (Sandwell and Smith, 2009).

647 Figure 3. Six tested numerical setups. a) Setup 1a: 4-layered weak rheology, crust $40 \mathrm{~km}$ thick, lithosphere $648200 \mathrm{~km}$ thick. b) Setup 1b: strong 4-layered rheology, crust $40 \mathrm{~km}$ thick, lithosphere $200 \mathrm{~km}$ thick. c) Setup 649 2a: combined rheological profiles (weak on the left side, strong on the right side), crust $40 \mathrm{~km}$ thick, and 
lithosphere $200 \mathrm{~km}$ (equal for both rheologies). d) Setup 2b: combined rheological strength envelopes,

651 (weak on the left side, strong on the right side), crust $30 \mathrm{~km}$ thick on the right side and $40 \mathrm{~km}$ thick on the 652 left side, lithosphere $180 \mathrm{~km}$ thick on the left side and $200 \mathrm{~km}$ thick on the right side, no complex contact 653 geometries. e) Setup 3a: combined rheological strength envelopes, (weak on the left side, strong on the right 654 side), crust $30 \mathrm{~km}$ thick on the right side and $40 \mathrm{~km}$ thick on the left side; lithosphere $180 \mathrm{~km}$ thick on the 655 left side and $200 \mathrm{~km}$ thick on the right side. The contact between the two different crustal thicknesses is a 656 low-angle geometry, dipping towards the right. f). Setup 3b: combined rheological strength envelopes, 657 (weak on the left side, strong on the right side), crust $30 \mathrm{~km}$ on the right side and $40 \mathrm{~km}$ thick on the left 658 side, lithosphere $180 \mathrm{~km}$ thick on the left side and $200 \mathrm{~km}$ thick on the right side. The contact between the 659 two different crustal thicknesses is a low-angle geometry dipping towards the left.

661 Figure 4. Models with different rheology and plume location showing the most representative examples of 662 the three modes of continental break-up. a) "Centred": Experiment 6, Setup 1, with a strong rheology and 663 the anomaly located at $1200 \mathrm{~km}(200 \mathrm{~km}$ offset from the centre towards the right). At 2.1 Myr the first topographic response occurs. The break-up axis develops directly above the initial mantle plume position and mantle material reaches the surface. b) "Shifted": Experiment 12, Setup 2, with a laterally varying rheology and the anomaly positioned in the centre at $1000 \mathrm{~km}$. At $2.1 \mathrm{Myr}$ the first topographic variation shows with a larger extend than the "centred" break-up model. The break-up axis develops offset from the original mantle plume location and mantle material migrates towards the spreading centre, reaching the surface. c) "Distant”: Experiment 23, Setup 3, has a laterally varying rheology and the anomaly is positioned in the centre at $1000 \mathrm{~km}$. At 2.1 Myr minor topographic variation. The break-up axis develops far offset

671 from the original mantle plume location and the mantle plume remains glued to the base of the lithosphere.

672 The initial topographic variations remain visible after break-up.

674 Figure 5. Examples of models with different setup, plume location rheological structure showing the 675 different modes of break-up; a-c) "centred" examples, d-f) "shifted” examples, g-i) “distant” examples. In 
red the initial location of the mantle anomaly is drawn. The graphs below show the normalised, statistical likelihood of a mode (“centred", "shifted" or "distant") for a given setups.

678

Figure 6. Evolution of 3D model a) rapid plume uplift leading to formation of linear extension-perpendicular rift at the crustal level; b-c) development of wide rift basin with localized crustal high strain along bounding normal faults; gradual cooling and solidification of plume head material; d) widely distributed rift above 682 completely crystallized plume head ponding lithosphere-asthenosphere boundary; e) rapid transition from 683 deformation localized in normal faults bounding wide rift valley to localized strain within narrow zones 684 associated with localized plume ascent; f) breakup of the continental lithosphere along spreading zone 685 considerably shifted from centre of the mantle plume. Bulk of plume material is shown in pale orange. Green 686 to red colours indicate strain rate at the level of $10 \mathrm{~km}$ (i.e. within upper crust). Component distribution is shown for vertical cross-sections trough central part of the model domain.

Figure 7. Detailed display of experiment 12. Setup 2 is the base for this experiment with a laterally varying 690 rheology. The anomaly is positioned in the centre of the model at $1000 \mathrm{~km}$. At $2.1 \mathrm{Myr}$ the first topographic variation shows with a larger extend than the "centred" break-up model. Strain rate localizes slightly shifted from the plume impingement point at 3.1 Myr. Strain localizes, topography variations grow and crustal break-up occurs at 8.1 Myr. Mantle material slowly migrates towards the spreading centre reaching the surface until the material that remains below the lithosphere reaches thermal equilibrium around $22 \mathrm{Myr}$.

Figure 8. Schematic representation of the three modes of break-up. a) The very early phase of rifting $(0-$ 6975 Myr) is very similar for all three modes after which they develop into b) "Centred"; c) "shifted" and d) "distant". An example of a simplified interpretation of the Uruguayan margin (after Clerc et al., 2015) is used to demonstrate the resemblance of the "shifted" mode of break-up, like experiment 12, with the South Atlantic domain. e) Map showing the outline of the plate configuration at the moment of break-up 
701 between Africa and South America on the lower mantle low velocity zone (South African Super Plume)

702 (from Davaille et al., 2005). The Parana-Etendeka flood basalts are depicted in green (after Torsvik et al.,

703 2009). The orange dots refer to the three possible principal locations of initial thermal anomaly at the

704 upper/lower mantle boundary corresponding to the Tristan plume

705

706 Table caption

707 Table 1. Summary of the thermal and mechanical parameters used for this study. 1) Turcotte and Schubert 708 (2002), 2) Ranalli (1995); 3) d'Acremont et al. (2003) and references therein; 4) Tsenn and Carter (1987);

709 5) Burov and Poliakov (2001).

710

711 Table 2. Controlling parameters and principal results of the experiments. 


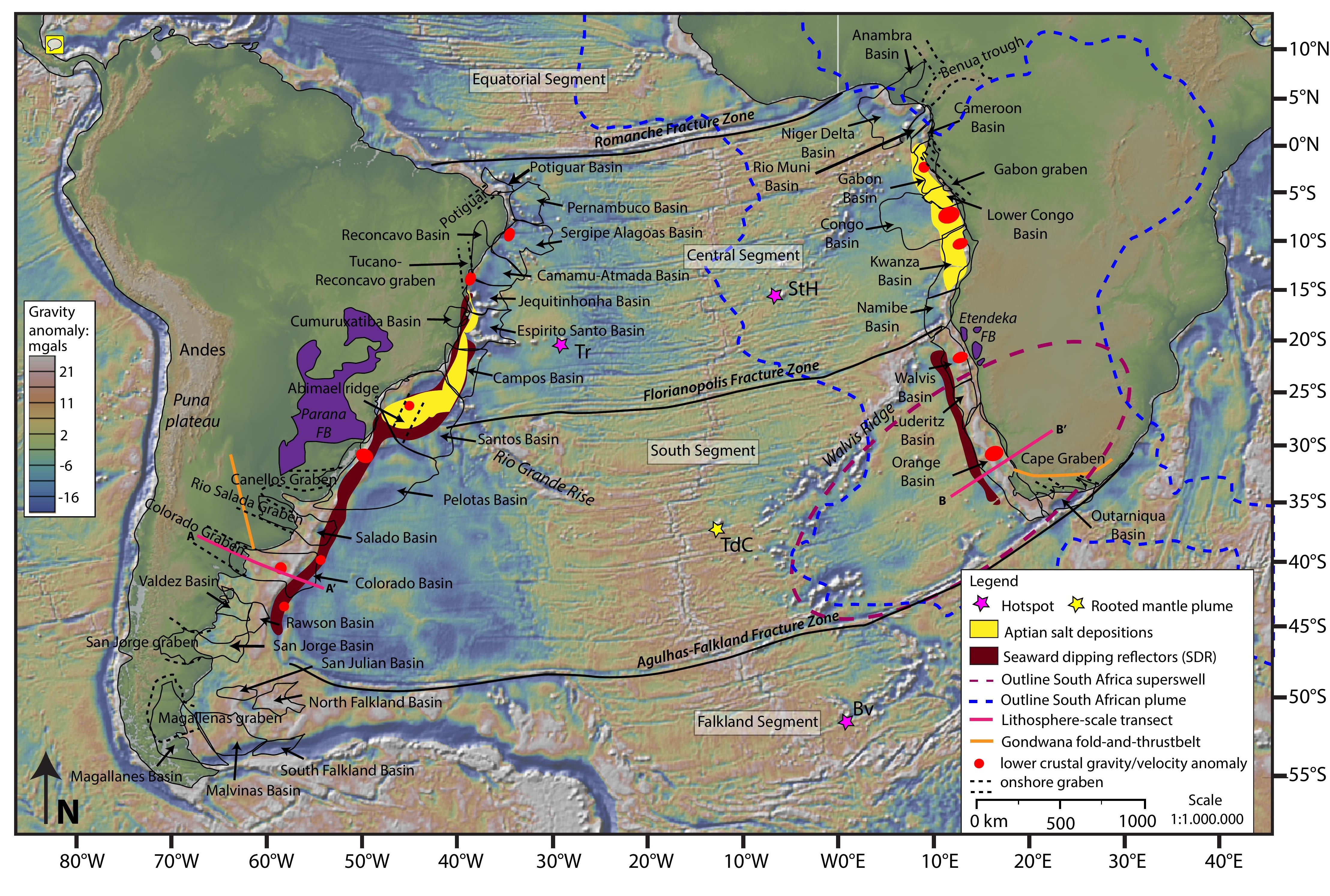




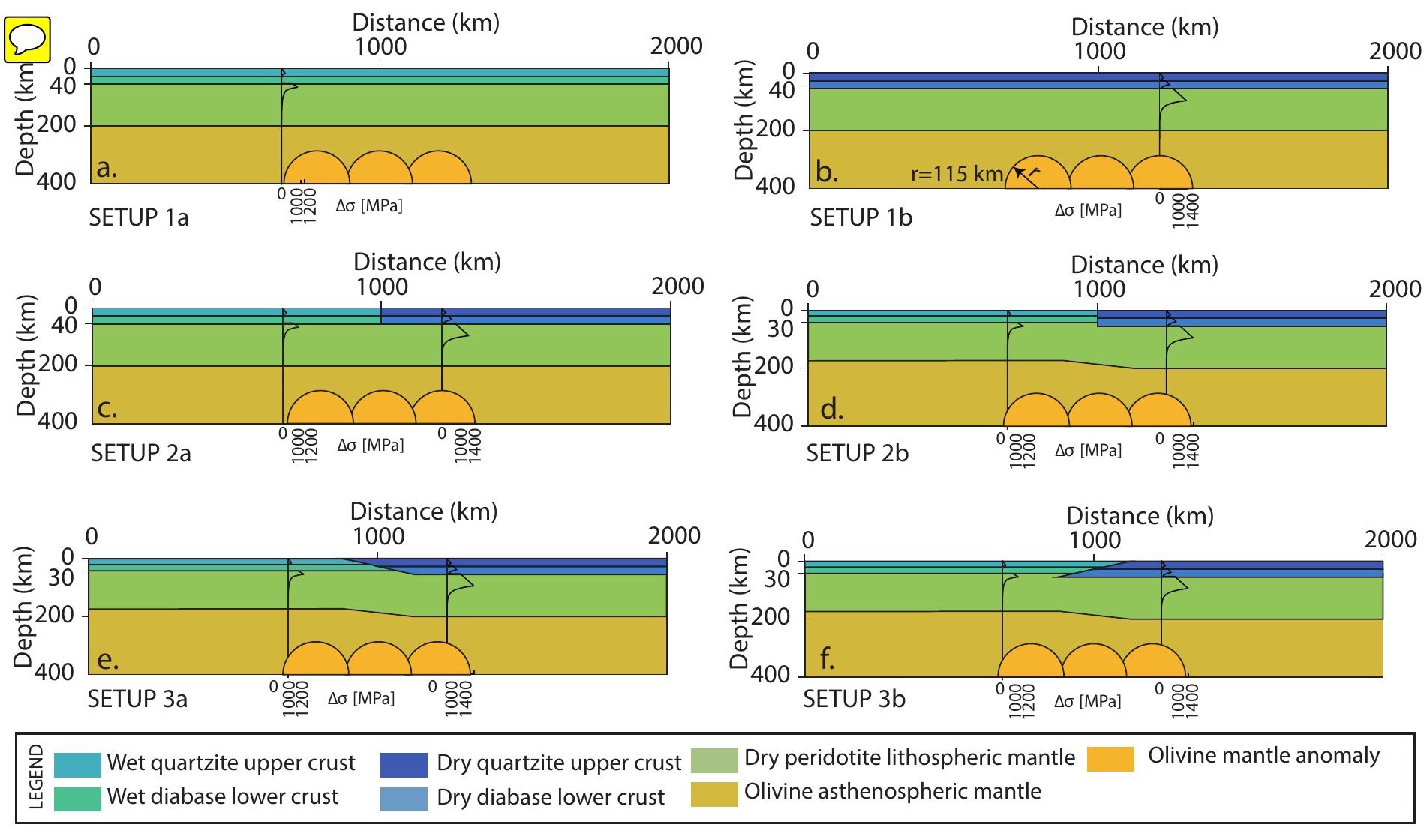




\section{“Central" break-up}

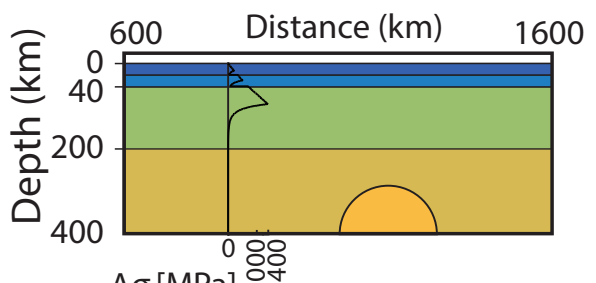

$\Delta \sigma[\mathrm{MPa}] \stackrel{\circ}{-}$

Phase
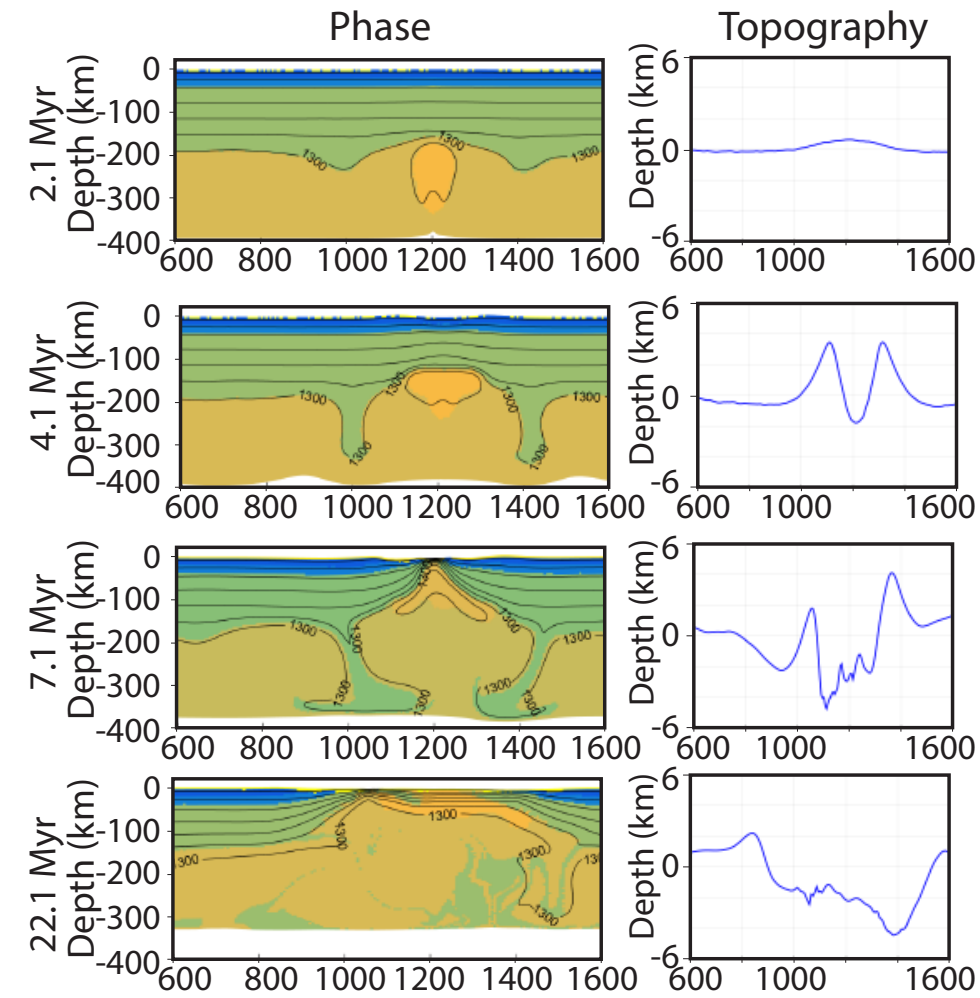

a. Experiment 6

\section{"Shifted" break-up}

“Distant" break-up
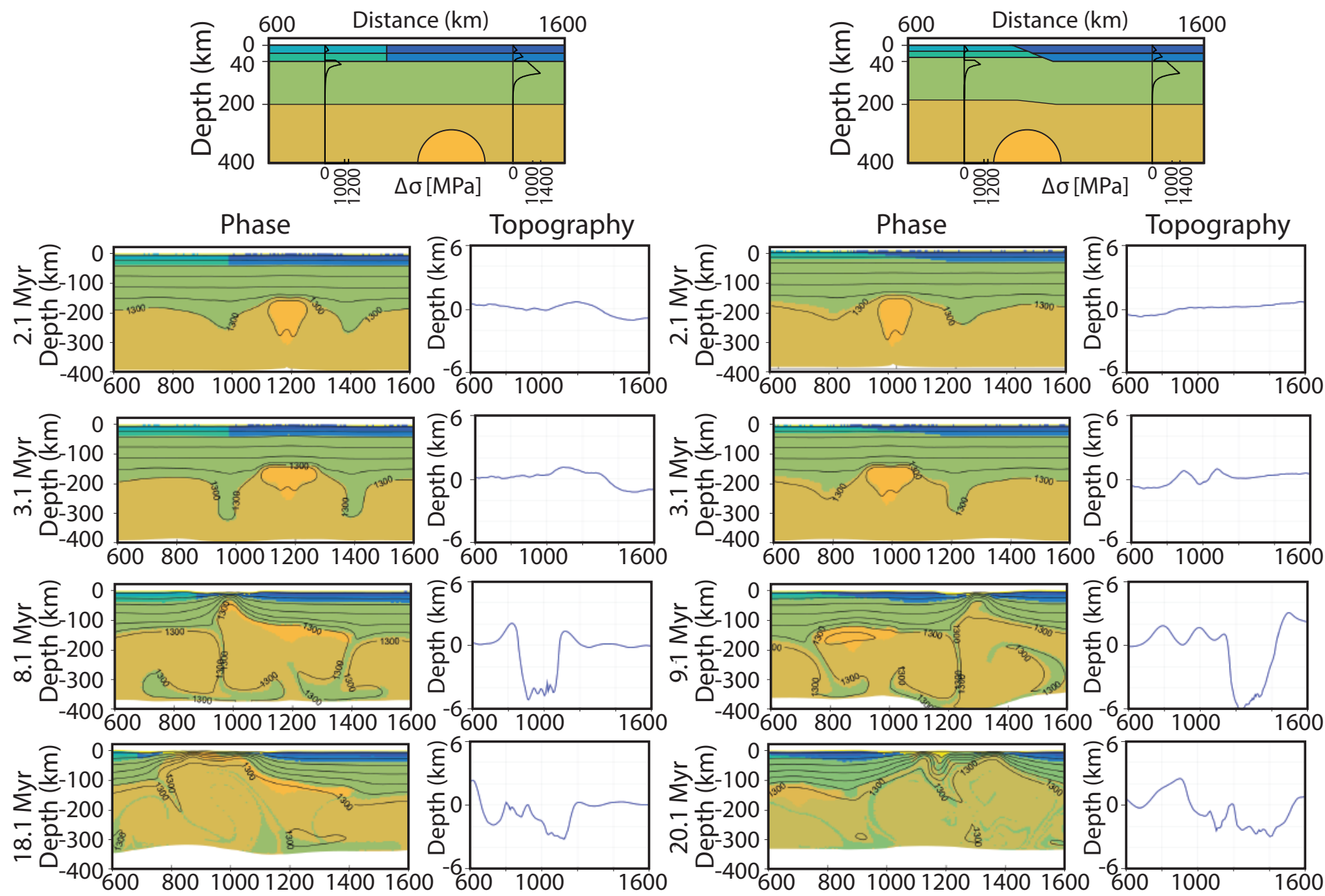

b. Experiment 12

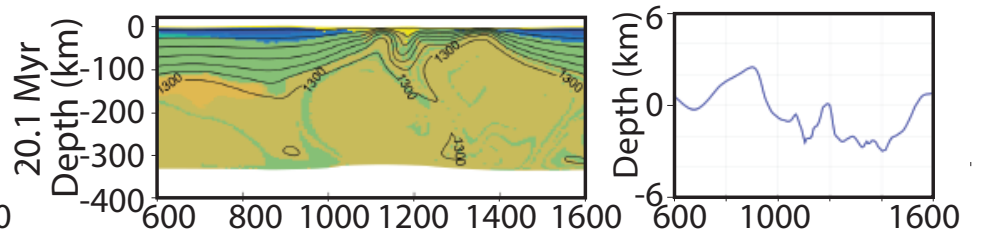

c. Experiment 23 
“Central” break-up

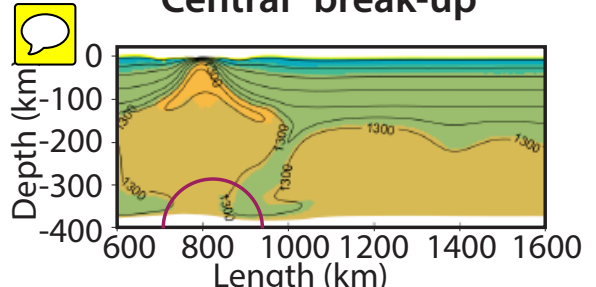

a. Experiment 1 @ 7 Myr
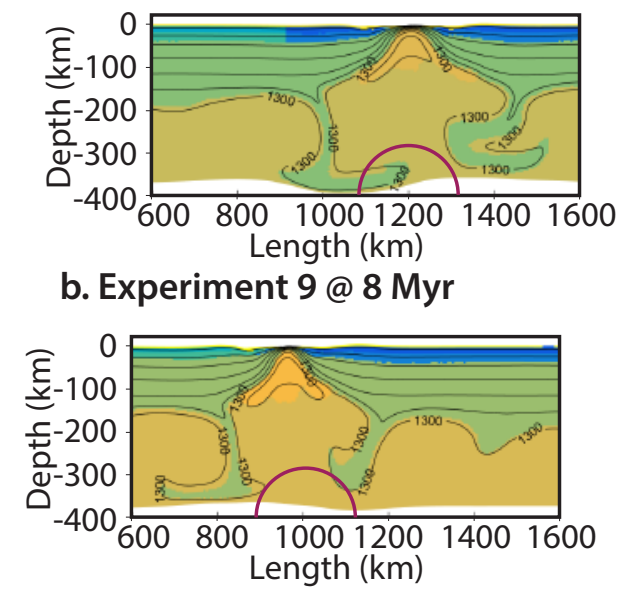

c. Experiment 17 @ 7 Mr

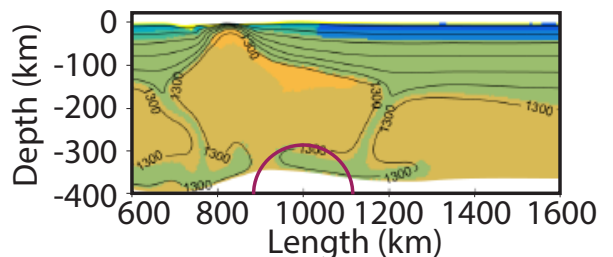

d. Experiment 11 @ Myr

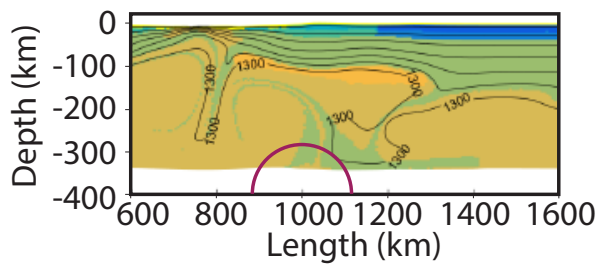

e. Experiment 8 @ 17 Myr

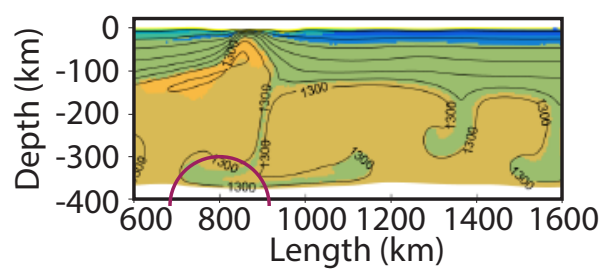

f. Experiment 34 @ 9 Myr

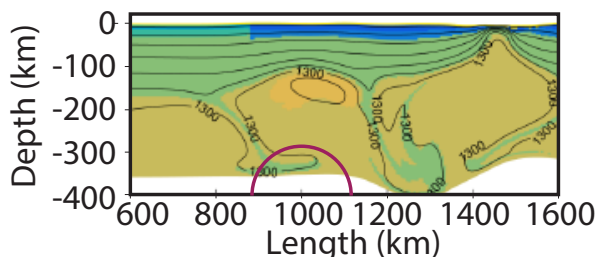

g. Experiment 14 @ 11 Myr

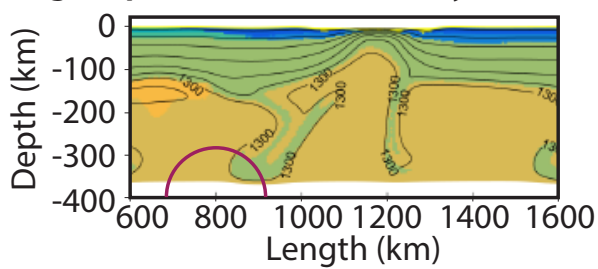

h. Experiment 22 @ 10 Myr

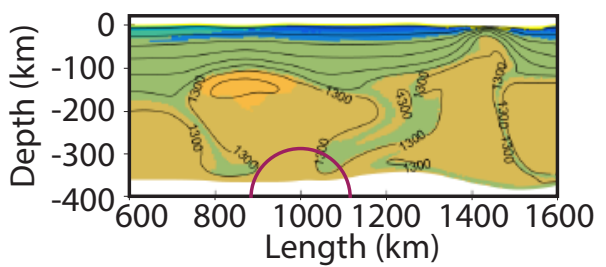

i. Experiment 35 @ 10 Myr
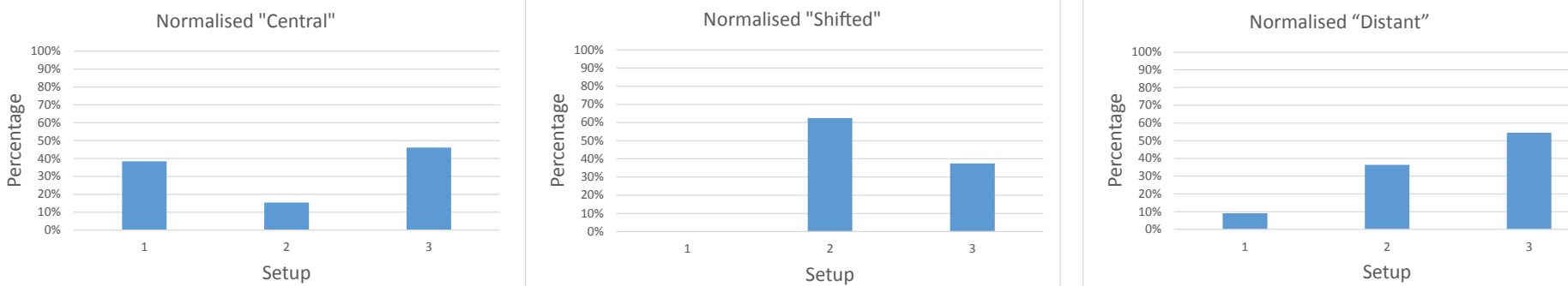

Normalised "Shifted"
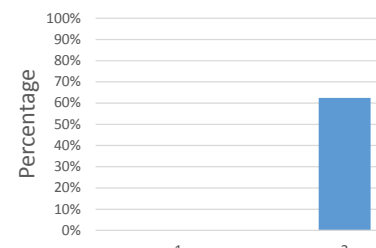

Setup

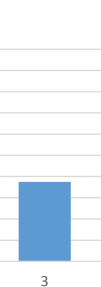

Setup 
Phase

$\approx \frac{\varepsilon}{\approx}-100$

है

$\bar{\sim} \stackrel{\circ}{\mathrm{D}}-300$

$-400$

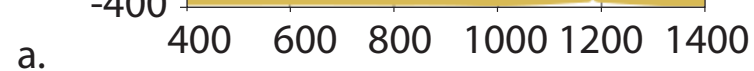

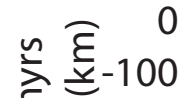

$\varepsilon \mp-200$

ले $\frac{\circ}{\grave{\nu}}-300$

b. $\quad 400 \quad 4000 \quad 800 \quad 100012001400$

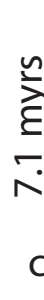

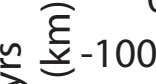

0

300

$-400400 \quad 600800100012001400$

$\infty$

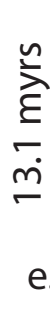

$$
\begin{aligned}
& \text { 气 } \\
& \text { है } \\
& \stackrel{\infty}{\infty} \\
& \mathrm{f}
\end{aligned}
$$

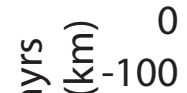

$\varepsilon \approx-200$

등 은-300

f. $\quad 400 \quad 600 \quad 800 \quad 1000 \quad 1200 \quad 1400$

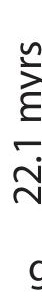

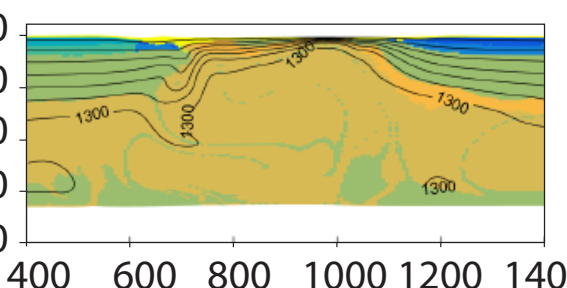

Topography
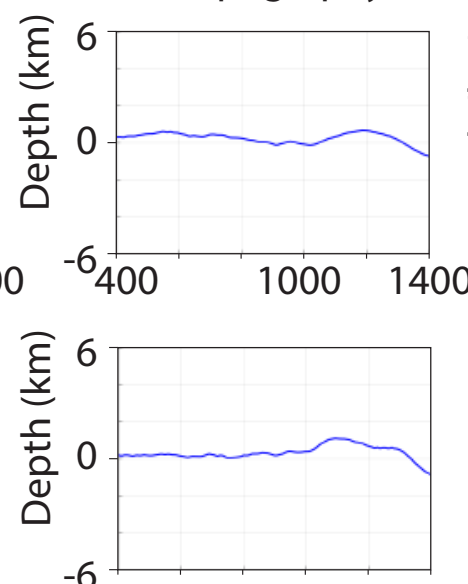

$1000 \quad 1400$
Strain rate
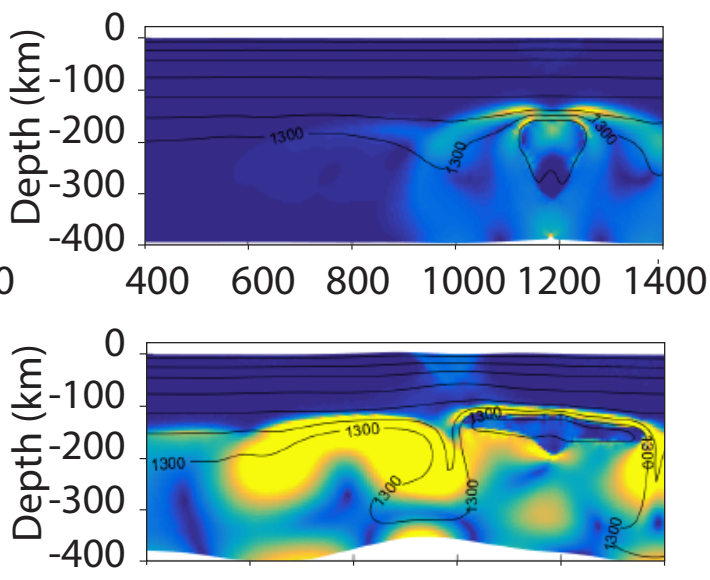

$\begin{array}{lllll}400 & 600 & 800 & 10001200 & 1400\end{array}$

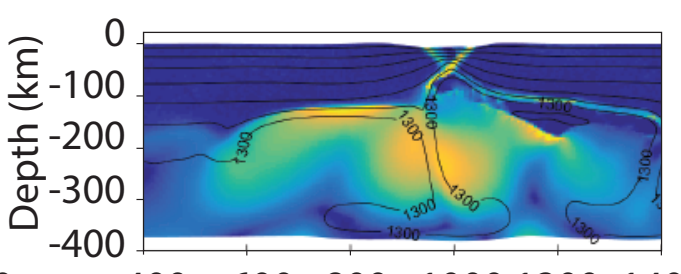

$\begin{array}{lllll}400 & 600 & 800 & 10001200 & 1400\end{array}$

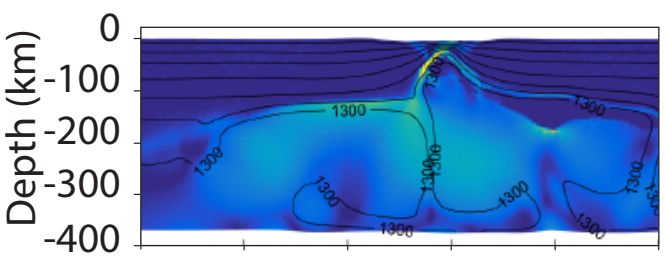

$\begin{array}{lllll}400 & 600 & 800 & 10001200 & 1400\end{array}$
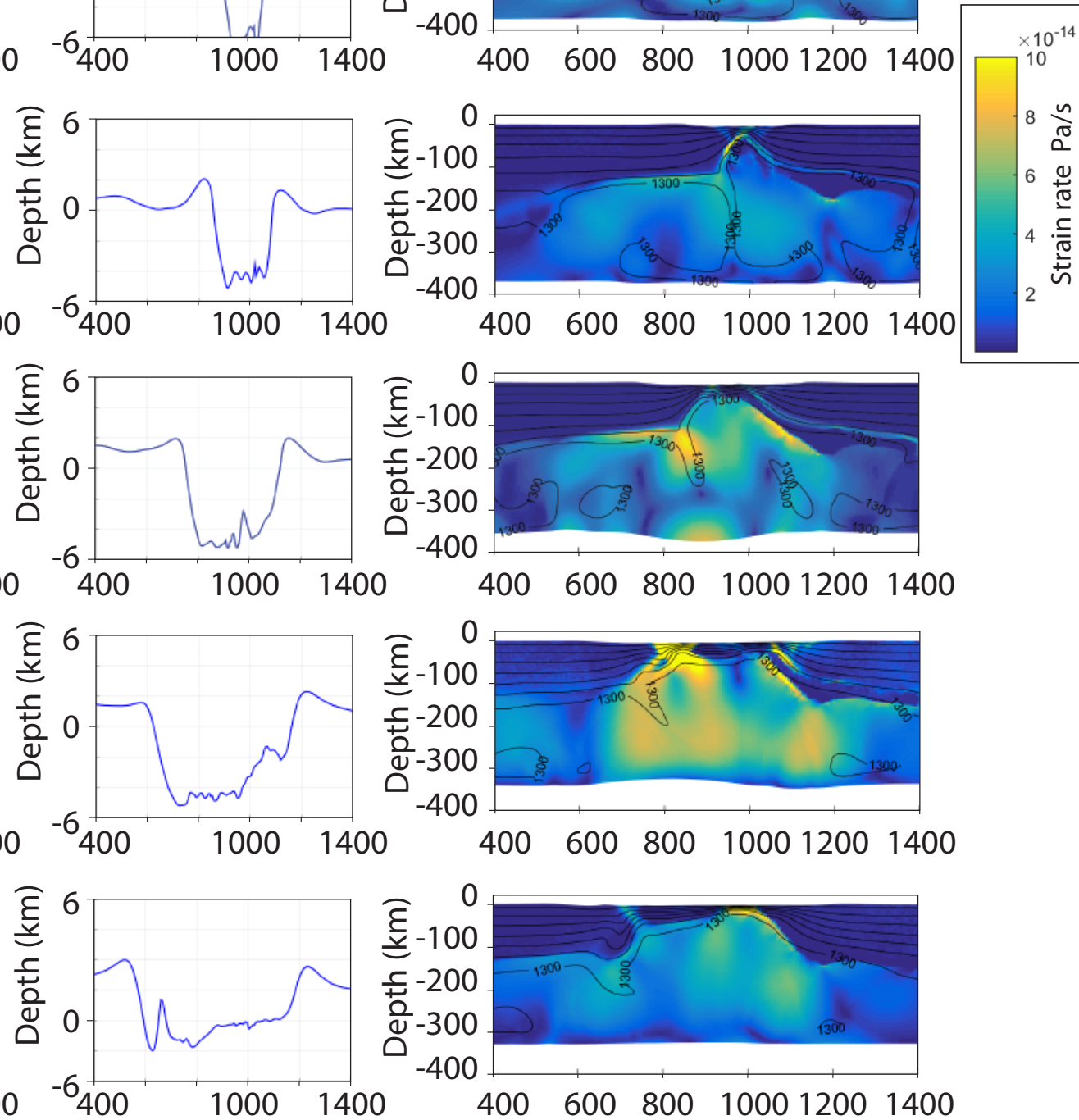
b.

"Central" break-up

a.<smiles>C1CC2CC1C2</smiles>

$$
0 \text { - } 5 \mathrm{Myr}
$$

$\mathrm{MOHO}$ weak lithosphere strong lithosphere
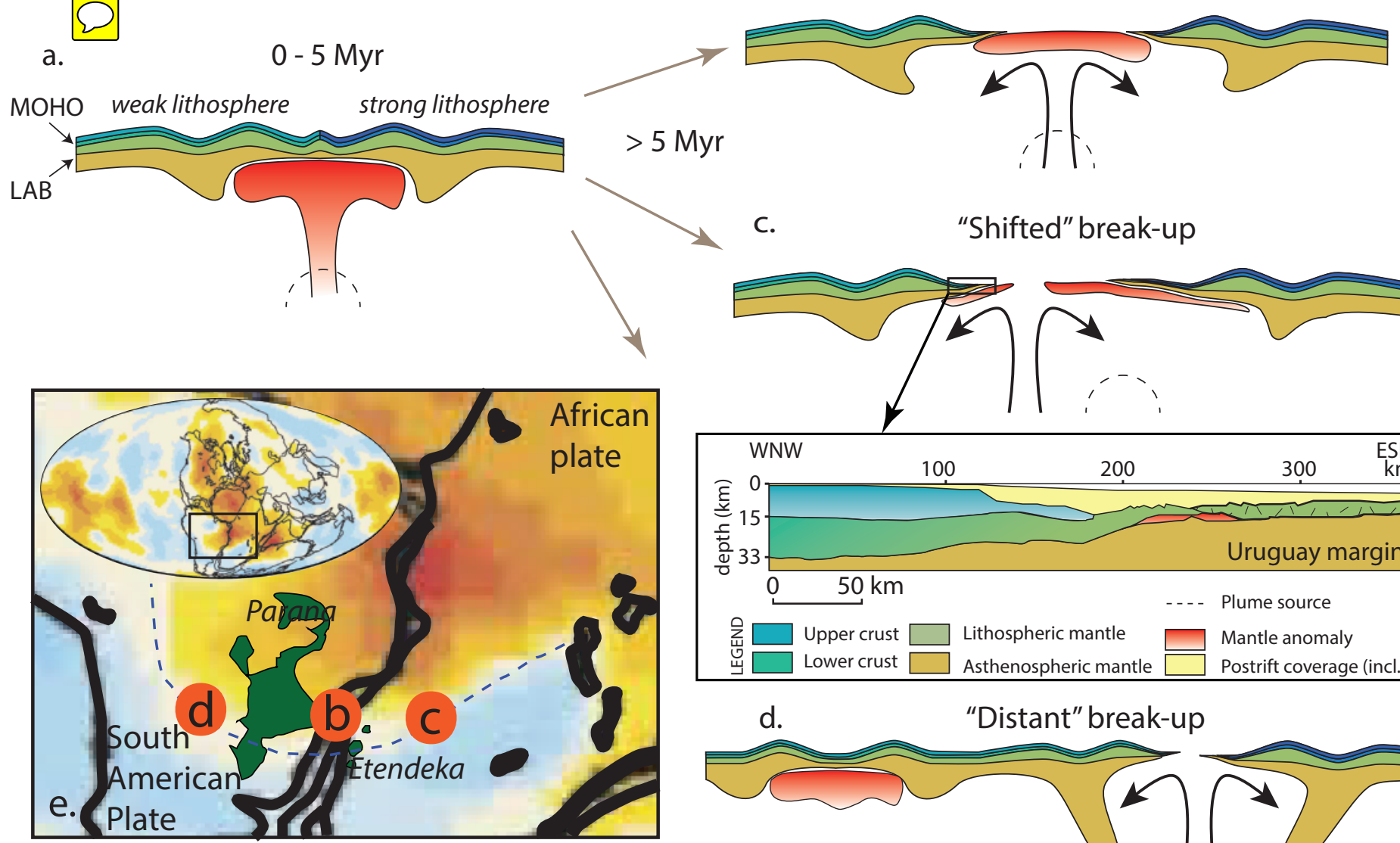

c.

"Shifted" break-up
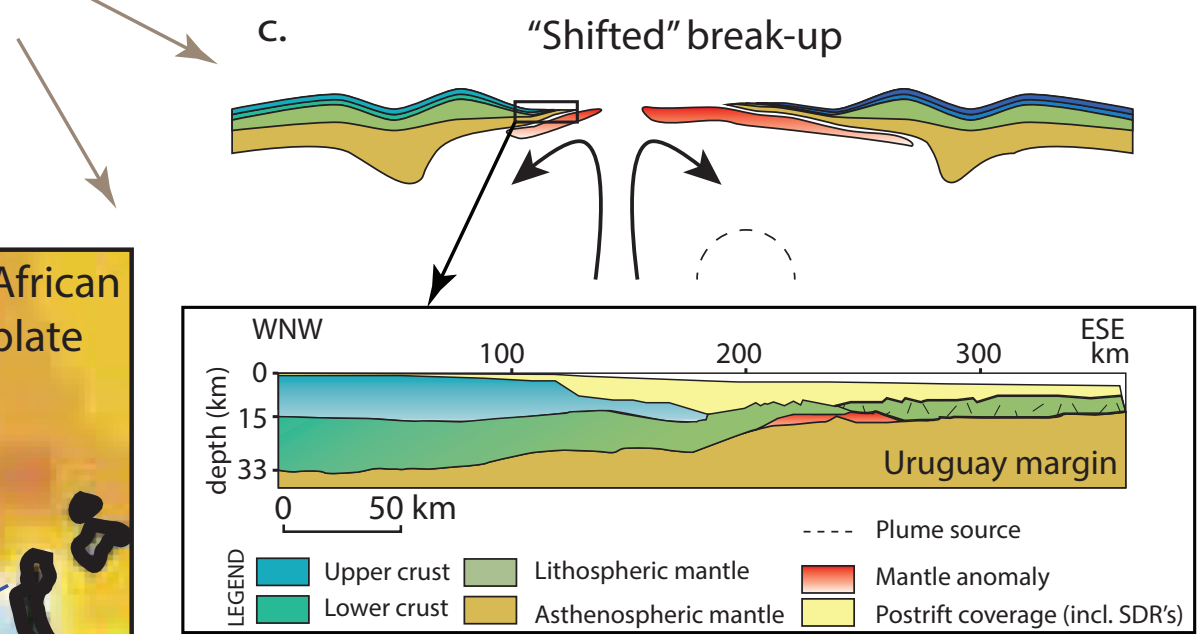

d.

“Distant" break-up

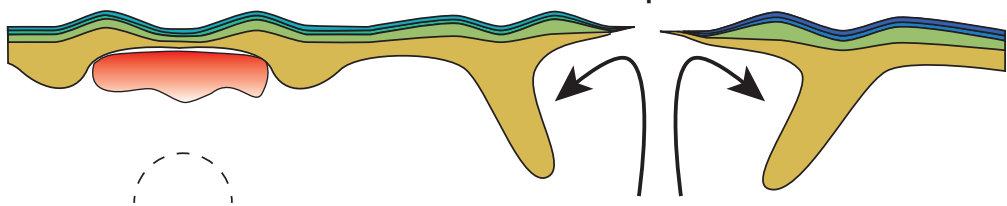




\section{Table 1}

\begin{tabular}{|c|c|c|c|c|}
\hline Thermal parameters & Thermal property & Value & Unit & Ref. \\
\hline & Surface temperature & 10 & ${ }^{\circ} \mathrm{C}$ & 1 \\
\hline & Temperature at the base of the thermal lithosphere & 1330 & ${ }^{\circ} \mathrm{C}$ & \\
\hline & Temperature at the base of the upper mantle & 1400 & ${ }^{\circ} \mathrm{C}$ & \\
\hline & Temperature mantle anomaly & 1700 & ${ }^{\circ} \mathrm{C}$ & \\
\hline & Thermal conductivity crust & 2.5 & $\mathrm{~W} / \mathrm{m}{ }^{\circ} \mathrm{C}$ & \\
\hline & Thermal conductivity mantle & 3.5 & $\mathrm{~W} / \mathrm{m}{ }^{\circ} \mathrm{C}$ & \\
\hline & Radiogenic heat production at the surface & $1.5 \mathrm{E}-9$ & $\mathrm{~W} / \mathrm{kg}$ & \\
\hline & Radius radiogenic heat & 10 & $\mathrm{~km}$ & \\
\hline & Thermo-tectonic age of the lithosphere & 500 & myrs & \\
\hline & Surface heat flow & 40 & $\mathrm{~mW} / \mathrm{m}^{\wedge} 2$ & \\
\hline & Mantle heat flow & 15 & $\mathrm{~mW} / \mathrm{m}^{\wedge} 2$ & \\
\hline Mechanical parameters & Mechanical property & & & \\
\hline Strong upper crust & density & 2600 & $\mathrm{~kg} / \mathrm{m}^{\wedge} 3$ & 2 \\
\hline Dry quarts & Viscosity parameter $\mathrm{N}$ & 3 & & \\
\hline & Viscosity parameter A & $6.8 \mathrm{e}-6$ & $\mathrm{MPa}^{\wedge}-n / \mathrm{s}^{\wedge}-1$ & \\
\hline & Viscosity parameter $\mathrm{E}$ & $1.56 \mathrm{e} 5$ & $\mathrm{~J} / \mathrm{mol}$ & \\
\hline Strong lower crust & density & 2850 & $\mathrm{~kg} / \mathrm{m}^{\wedge} 3$ & 3 \\
\hline Strong diabase & Viscosity parameter $\mathrm{N}$ & 3.05 & & \\
\hline & Viscosity parameter A & $6.3 e-2$ & $\mathrm{Mpa}^{\wedge}-\mathrm{n} / \mathrm{s}^{\wedge}-1$ & \\
\hline & Viscosity parameter E & $2.76 \mathrm{e} 5$ & $\mathrm{~J} / \mathrm{mol}$ & \\
\hline Weak upper crust & density & 2500 & $\mathrm{~kg} / \mathrm{m}^{\wedge} 3$ & 2 \\
\hline Wet quartz & Viscosity parameter $\mathrm{N}$ & 2.3 & & \\
\hline & Viscosity parameter A & $3.2 \mathrm{e}-4$ & $\mathrm{Mpa}^{\wedge}-\mathrm{n} / \mathrm{s}^{\wedge}-1$ & \\
\hline & Viscosity parameter E & $1.54 \mathrm{e} 5$ & $\mathrm{~J} / \mathrm{mol}$ & \\
\hline Weak lower crust & density & 2750 & $\mathrm{~kg} / \mathrm{m}^{\wedge} 3$ & 4 \\
\hline Weak diabase & Viscosity parameter $\mathrm{N}$ & 4.7 & & \\
\hline & Viscosity parameter A & $1.9 \mathrm{e} 2$ & $\mathrm{Mpa}^{\wedge}-\mathrm{n} / \mathrm{s}^{\wedge}-1$ & \\
\hline & Viscosity parameter E & $4.85 \mathrm{e} 5$ & $\mathrm{~J} / \mathrm{mol}$ & \\
\hline Lithospheric mantle & density & 3330 & $\mathrm{~kg} / \mathrm{m}^{\wedge} 3$ & 2 \\
\hline Peridotite & Viscosity parameter $\mathrm{N}$ & 3.5 & & \\
\hline & Viscosity parameter A & $2.5 \mathrm{e} 4$ & $\mathrm{Mpa}^{\wedge}-\mathrm{n} / \mathrm{s}^{\wedge}-1$ & \\
\hline & Viscosity parameter E & $5.32 \mathrm{e} 5$ & $\mathrm{~J} / \mathrm{mol}$ & \\
\hline Asthenosphere & density & 3310 & $\mathrm{~kg} / \mathrm{m}^{\wedge} 3$ & 3 \\
\hline Olivine & Viscosity parameter $\mathrm{N}$ & 3.2 & & \\
\hline & Viscosity parameter A & $7.0 \mathrm{e} 3$ & $\mathrm{Mpa}^{\wedge}-\mathrm{n} / \mathrm{s}^{\wedge}-1$ & \\
\hline & Viscosity parameter E & $5.1 \mathrm{e} 5$ & $\mathrm{~J} / \mathrm{mol}$ & \\
\hline Plume & density & 3250 & $\mathrm{~kg} / \mathrm{m}^{\wedge} 3$ & 3 \\
\hline Olivine & Viscosity parameter $\mathrm{N}$ & 3.5 & & \\
\hline & Viscosity parameter A & $5 . \mathrm{e} 14$ & $\mathrm{Mpa}^{\wedge}-\mathrm{n} / \mathrm{s}^{\wedge}-1$ & \\
\hline & Viscosity parameter E & $5.2 \mathrm{e} 5$ & $\mathrm{~J} / \mathrm{mol}$ & \\
\hline & Friction angle & 30 & $\bar{\circ}$ & \\
\hline & Lamé elastic constant $\lambda=\mathrm{G}$ & 25 & GPa & \\
\hline & Cohesion & 20 & $\mathrm{MPa}$ & \\
\hline & Erosion coefficient (a) & 500 & $\mathrm{~m}^{\wedge} 2 / \mathrm{yr}$ & 5 \\
\hline
\end{tabular}


Table 2

\begin{tabular}{|c|c|c|c|c|c|c|c|c|c|c|}
\hline & \multicolumn{2}{|c|}{$\begin{array}{l}\text { Controlling parameters } \\
\text { Boundary conditions }\end{array}$} & \multicolumn{3}{|c|}{ Mantle plume properties } & \multirow{2}{*}{$\begin{array}{l}\text { Setup } \\
\text { Initial geometry }\end{array}$} & \multicolumn{4}{|l|}{ Results } \\
\hline & $\begin{array}{l}\text { Extension } \\
\text { rate (left) }\end{array}$ & $\begin{array}{l}\text { Extension } \\
\text { rate (right) }\end{array}$ & Plume location & $\begin{array}{l}\text { Density } \\
\left(\mathrm{kg} / \mathrm{m}^{\wedge} 3\right)\end{array}$ & $\begin{array}{l}\text { Diameter } \\
(\mathbf{k m})\end{array}$ & & Break-up point & $\begin{array}{l}\text { Above center } \\
\text { anomaly? }\end{array}$ & $\begin{array}{l}\text { Break-up } \\
\text { mechanism }\end{array}$ & Figure \\
\hline 1 & $12.5 \mathrm{~mm} / \mathrm{yr}$ & $12.5 \mathrm{~mm} / \mathrm{yr}$ & $800 \mathrm{~km}$ & 3250 & 230 & Setup 1a & $800 \mathrm{~km}$ & yes & Central & $5 \mathrm{a}$ \\
\hline 2 & $12.5 \mathrm{~mm} / \mathrm{yr}$ & $12.5 \mathrm{~mm} / \mathrm{yr}$ & $1000 \mathrm{~km}$ & 3250 & 230 & Setup 1a & $1500 \mathrm{~km}$ & no & Distant & \\
\hline 3 & $12.5 \mathrm{~mm} / \mathrm{yr}$ & $12.5 \mathrm{~mm} / \mathrm{yr}$ & $1200 \mathrm{~km}$ & 3250 & 230 & Setup 1a & $1200 \mathrm{~km}$ & yes & Central & \\
\hline 4 & $12.5 \mathrm{~mm} / \mathrm{yr}$ & $12.5 \mathrm{~mm} / \mathrm{yr}$ & 800 km & 3250 & 230 & Setup 1b & $800 \mathrm{~km}$ & yes & Central & \\
\hline 5 & $12.5 \mathrm{~mm} / \mathrm{yr}$ & $12.5 \mathrm{~mm} / \mathrm{yr}$ & $1000 \mathrm{~km}$ & 3250 & 230 & Setup 1b & $1000 \mathrm{~km}$ & yes & Central & \\
\hline 6 & $12.5 \mathrm{~mm} / \mathrm{yr}$ & $12.5 \mathrm{~mm} / \mathrm{yr}$ & $1200 \mathrm{~km}$ & 3250 & 230 & Setup $1 b$ & $1200 \mathrm{~km}$ & yes & Central & $4 \mathrm{a}$ \\
\hline 7 & $12.5 \mathrm{~mm} / \mathrm{yr}$ & $12.5 \mathrm{~mm} / \mathrm{yr}$ & $800 \mathrm{~km}$ & 3250 & 230 & Setup 2a & $850 \mathrm{~km}$ & no & Shifted & \\
\hline 8 & $12.5 \mathrm{~mm} / \mathrm{yr}$ & $12.5 \mathrm{~mm} / \mathrm{yr}$ & $1000 \mathrm{~km}$ & 3250 & 230 & Setup 2a & $800 \mathrm{~km}$ & no & Shifted & $5 \mathrm{e}$ \\
\hline 9 & $12.5 \mathrm{~mm} / \mathrm{yr}$ & $12.5 \mathrm{~mm} / \mathrm{yr}$ & $1200 \mathrm{~km}$ & 3250 & 230 & Setup $2 \mathrm{a}$ & $1200 \mathrm{~km}$ & yes & Central & $5 b$ \\
\hline 10 & $20 \mathrm{~mm} / \mathrm{yr}$ & $5 \mathrm{~mm} / \mathrm{yr}$ & 800 km & 3250 & 230 & Setup 2a & $750 \mathrm{~km}$ & no & Shifted & \\
\hline 11 & $20 \mathrm{~mm} / \mathrm{yr}$ & $5 \mathrm{~mm} / \mathrm{yr}$ & $1000 \mathrm{~km}$ & 3250 & 230 & Setup $2 \mathrm{a}$ & $800 \mathrm{~km}$ & no & Shifted & $5 \mathrm{~d}$ \\
\hline 12 & $20 \mathrm{~mm} / \mathrm{yr}$ & $5 \mathrm{~mm} / \mathrm{yr}$ & $1200 \mathrm{~km}$ & 3250 & 230 & Setup $2 \mathrm{a}$ & $1000 \mathrm{~km}$ & no & Shifted & $4 b / 7$ \\
\hline 13 & $12.5 \mathrm{~mm} / \mathrm{yr}$ & $12.5 \mathrm{~mm} / \mathrm{yr}$ & $800 \mathrm{~km}$ & 3250 & 230 & Setup $2 b$ & $1600 \mathrm{~km}$ & no & Distant & \\
\hline 14 & $12.5 \mathrm{~mm} / \mathrm{yr}$ & $12.5 \mathrm{~mm} / \mathrm{yr}$ & $1000 \mathrm{~km}$ & 3250 & 230 & Setup $2 b$ & $1450 \mathrm{~km}$ & no & Distant & $5 \mathrm{~g}$ \\
\hline 15 & $12.5 \mathrm{~mm} / \mathrm{yr}$ & $12.5 \mathrm{~mm} / \mathrm{yr}$ & $1200 \mathrm{~km}$ & 3250 & 230 & Setup $2 b$ & $\mathrm{xxx}$ & $\mathrm{xxx}$ & no break-up & \\
\hline 16 & $20 \mathrm{~mm} / \mathrm{yr}$ & $5 \mathrm{~mm} / \mathrm{yr}$ & $800 \mathrm{~km}$ & 3250 & 230 & Setup $2 b$ & $1200 \mathrm{~km}$ & no & Distant & \\
\hline 17 & $20 \mathrm{~mm} / \mathrm{yr}$ & $5 \mathrm{~mm} / \mathrm{yr}$ & $1000 \mathrm{~km}$ & 3250 & 230 & Setup 2b & $1000 \mathrm{~km}$ & yes & Central & $5 c$ \\
\hline 18 & $20 \mathrm{~mm} / \mathrm{yr}$ & $5 \mathrm{~mm} / \mathrm{yr}$ & $1200 \mathrm{~km}$ & 3250 & 230 & Setup 2b & $1700 \mathrm{~km}$ & no & Distant & \\
\hline 19 & $12.5 \mathrm{~mm} / \mathrm{yr}$ & $12.5 \mathrm{~mm} / \mathrm{yr}$ & 800 km & 3250 & 230 & Setup 3a & $1200 \mathrm{~km}$ & no & Distant & \\
\hline 20 & $12.5 \mathrm{~mm} / \mathrm{yr}$ & $12.5 \mathrm{~mm} / \mathrm{yr}$ & $1000 \mathrm{~km}$ & 3250 & 230 & Setup 3a & $1000 \mathrm{~km}$ & yes & Central & \\
\hline 21 & $12.5 \mathrm{~mm} / \mathrm{yr}$ & $12.5 \mathrm{~mm} / \mathrm{yr}$ & $1200 \mathrm{~km}$ & 3250 & 230 & Setup 3a & $1200 \mathrm{~km}$ & yes & Central & \\
\hline 22 & $20 \mathrm{~mm} / \mathrm{yr}$ & $5 \mathrm{~mm} / \mathrm{yr}$ & 800 km & 3250 & 230 & Setup 3a & $1200 \mathrm{~km}$ & no & Distant & $5 \mathrm{~h}$ \\
\hline 23 & $20 \mathrm{~mm} / \mathrm{yr}$ & $5 \mathrm{~mm} / \mathrm{yr}$ & $1000 \mathrm{~km}$ & 3250 & 230 & Setup 3a & $1300 \mathrm{~km}$ & no & Distant & $4 c$ \\
\hline 24 & $20 \mathrm{~mm} / \mathrm{yr}$ & $5 \mathrm{~mm} / \mathrm{yr}$ & $1200 \mathrm{~km}$ & 3250 & 230 & Setup 3a & $1250 \mathrm{~km}$ & yes & Shifted & \\
\hline 31 & $12.5 \mathrm{~mm} / \mathrm{yr}$ & $12.5 \mathrm{~mm} / \mathrm{yr}$ & $800 \mathrm{~km}$ & 3250 & 230 & Setup $3 b$ & $800 \mathrm{~km}$ & yes & Central & \\
\hline 32 & $12.5 \mathrm{~mm} / \mathrm{yr}$ & $12.5 \mathrm{~mm} / \mathrm{yr}$ & $1000 \mathrm{~km}$ & 3250 & 230 & Setup $3 b$ & $1000 \mathrm{~km}$ & yes & Central & \\
\hline 33 & $12.5 \mathrm{~mm} / \mathrm{yr}$ & $12.5 \mathrm{~mm} / \mathrm{yr}$ & $1200 \mathrm{~km}$ & 3250 & 230 & Setup 3b & $1200 \mathrm{~km}$ & yes & Central & \\
\hline 34 & $20 \mathrm{~mm} / \mathrm{yr}$ & $5 \mathrm{~mm} / \mathrm{yr}$ & 800 km & 3250 & 230 & Setup $3 b$ & 850 km & no & Shifted & $5 f$ \\
\hline 35 & $20 \mathrm{~mm} / \mathrm{yr}$ & $5 \mathrm{~mm} / \mathrm{yr}$ & $1000 \mathrm{~km}$ & 3250 & 230 & Setup $3 b$ & $1400 \mathrm{~km}$ & no & Distant & $5 \mathrm{i}$ \\
\hline 36 & $20 \mathrm{~mm} / \mathrm{yr}$ & $5 \mathrm{~mm} / \mathrm{yr}$ & $1200 \mathrm{~km}$ & 3250 & 230 & Setup 3b & $1700 \mathrm{~km}$ & no & Distant & \\
\hline
\end{tabular}

